May 2020

\title{
Intellectual Property's First Sale Doctrine and the Policy Against Restraints on Alienation
}

Lorie M. Graham

Suffolk University Law School, Igraham@suffolk.edu

Stephen M. McJohn

Suffolk University Law School, smcjohn@suffolk.edu

Follow this and additional works at: https://scholarship.law.tamu.edu/lawreview

Part of the Contracts Commons, and the Intellectual Property Law Commons

\section{Recommended Citation}

Lorie M. Graham \& Stephen M. McJohn, Intellectual Property's First Sale Doctrine and the Policy Against Restraints on Alienation, 7 Tex. A\&M L. Rev. 497 (2020).

Available at: https://doi.org/10.37419/LR.V7.I3.1

This Article is brought to you for free and open access by Texas A\&M Law Scholarship. It has been accepted for inclusion in Texas A\&M Law Review by an authorized editor of Texas A\&M Law Scholarship. For more information, please contact aretteen@law.tamu.edu. 


\title{
ARTICLES
}

\section{INTELLECTUAL PROPERTY'S FIRST SALE DOCTRINE AND THE POLICY AGAINST RESTRAINTS ON ALIENATION}

\author{
By: Lorie M. Graham* \& Stephen M. McJohn**
}

\section{TABle of Contents}

I. First Sale as Rooted in the Policy Against Restraints on Alienation ....................... 501

A. Early Cases .............................. 501

B. Recent First Sale Developments in the Supreme

Court ..................................... 504

1. The Kirtsaeng Decision .................. 504

2. The Lexmark Decision.................... 506

II. How Broadly Does the First Sale Extend, if iT is to Prevent Restraints on Alienation? ........... 509

A. Common Law View of Restraints on Alienation .... 511

B. "Reasonableness" of Restraints on Alienation ....... 514

III. Whether First Sale Preempts Resale Royalty Rights for Artists ........................ 520

A. Restraints on Alienation as Artists' Moral Rights.... 521

B. Resale Royalties as Restraints on Alienation........ 524

IV. "Licenses" to Avoid First Sale, as Restraints on Alienation ................................. 533

A. Vernor v. Autodesk, Inc. and its Aftermath ....... 534

B. Application of Vernor in Restraints on Alienation

Context .................................... 536

V. Conclusion .................................. 540

The first sale doctrine decouples intellectual property and physical property. Suppose, at an auction at Sotheby's, someone bought a contemporary painting by Chuck Close. ${ }^{1}$ The buyer now owns the physical painting, but the copyright to the painting remains with the owner of the copyright - the painter Chuck Close or whomever Close

\section{DOI: https://doi.org/10.37419/LR.V7.I3.1}

* Professor of Law, Suffolk University Law School.

** Professor of Law, Suffolk University Law School.

1. See Close v. Sotheby's, Inc., 894 F.3d 1061, 1064 (9th Cir. 2018) (analyzing whether first sale doctrine in federal copyright law preempted California's Resale Royalty Act). 
may have transferred the copyright to. ${ }^{2}$ Absent the first sale doctrine, if the buyer either sold the painting or displayed it to the public, the buyer would potentially infringe the copyright in the painting. ${ }^{3}$ The copyright owner has the exclusive right to display copies (including the original, the first $\operatorname{copy}^{4}$ ) of the painting to the public and to distribute copies to the public. ${ }^{5}$ However, the first sale doctrine provides that the owner of an authorized copy may display or distribute that particular copy without infringing. ${ }^{6}$ The distribution right and display right no longer apply; these rights are "exhausted." Permission from the copyright owner is not required to resell copyrighted works or to display them. ${ }^{8}$ First sale permits a broad swath of activity. Used bookstores, libraries, swap fests, eBay, students reselling casebooks, and many more may rely on first sale to protect their distribution of copyrighted works. ${ }^{9}$ Museums, galleries, archives, bookstores, and more can likewise display their copies of copyrighted works without infringing under first sale. First sale (more commonly called "exhaustion" in patent law ${ }^{10}$ ) also applies to

2. See 17 U.S.C. $\$ 202$ (2018) ("Ownership of a copyright, or of any of the exclusive rights under a copyright, is distinct from ownership of any material object in which the work is embodied. Transfer of ownership of any material object, including the copy or phonorecord in which the work is first fixed, does not of itself convey any rights in the copyrighted work embodied in the object; nor, in the absence of an agreement, does transfer of ownership of a copyright or of any exclusive rights under a copyright convey property rights in any material object.").

3. "Potentially" because there exists the possibility of fair use. See id. $\S 107$.

4. Id. § 101 ("The term 'copies' includes the material object, other than a phonorecord, in which the work is first fixed.").

5. See id. § 106(3) ("to distribute copies or phonorecords of the copyrighted work to the public by sale or other transfer of ownership, or by rental, lease, or lending"); $i d$. $\$ 106(5)$ ("to display the copyrighted work publicly").

6. See id. $\$ 109$ (a) ("Notwithstanding the provisions of section 106(3), the owner of a particular copy or phonorecord lawfully made under this title, or any person authorized by such owner, is entitled, without the authority of the copyright owner, to sell or otherwise dispose of the possession of that copy or phonorecord."); see also $\S 109$ (c) ("Notwithstanding the provisions of section 106(5), the owner of a particular copy lawfully made under this title, or any person authorized by such owner, is entitled, without the authority of the copyright owner, to display that copy publicly, either directly or by the projection of no more than one image at a time, to viewers present at the place where the copy is located.").

7. See, e.g., Shubha Ghosh \& Irene Calboli, Exhausting Intellectual Property Rights: A Comparative Law And Policy Analysis 6-7 (2018).

8. See, e.g., Kirtsaeng v. John Wiley \& Sons, Inc., 568 U.S. 519, 538-39 (2013) (applying first sale to copies made abroad).

9. "Without the exhaustion doctrine, the market for reselling or renting products would either not exist or would look very different." GHOsh \& CALBOLI, supra note 7 , at 6 .

10. See, e.g., Amelia Smith Rinehart, Contracting Patents: A Modern Patent Exhaustion Doctrine, 23 HARv. J.L. \& TECH. 483, 484 (2010) ("The patent exhaustion doctrine, also known as the first sale doctrine, evolved in the United States during the late nineteenth century to accommodate the free movement of patented goods in commerce. In its simplest statement, the doctrine operates to 'exhaust,' or extinguish, the exclusive rights of sale and use as to patented articles sold with the patent owner's authorization."). 
patented products. ${ }^{11}$ Someone who buys a patented product (such as a pharmaceutical, computing device, or printer cartridge) can use or resell that product without infringing the patent, even though the patent owner has the rights to exclude others from using or selling the invention. ${ }^{12}$ First sale enables markets for resale or lease of patent products, from printer cartridges to airplanes.

First sale has its limits. In copyright, it applies only to the rights to distribute and to display the work. ${ }^{13}$ The copyright owner also has the exclusive right to make copies, to adapt the work, and to perform the work publicly, which are not subject to first sale. ${ }^{14}$ The painting buyer would potentially infringe if the buyer made a copy of the painting ${ }^{15}$ or adapted it into another artwork, ${ }^{16}$ but the buyer could not infringe the performance right, because one cannot perform a painting. ${ }^{17}$ The owner of a copy of a musical work may infringe if she performs it in public, which is why bars need licenses to play copyrighted music, even using copies they have purchased. The owner of a copy of a movie may infringe if she adapted the movie, such as making a sequel-or even dubbing the movie in another language. In patent, first sale likewise would not authorize the purchaser of a product to make additional copies. Similarly, first sale in patent would authorize the buyer of a patented item to use it or resell it, but not to make another one. ${ }^{18}$

First sale is long-established, by statute in copyright and by judicial interpretation in patent. The underlying policy of first sale, however, has been unsettled. ${ }^{19}$ First sale can be seen to rest on either of two rationales. $^{20}$ The first is a contract-based, gap-filler approach. If

11. First sale applies also within trademark law but triggers significantly different policy concerns. See David W. Barnes, Free-Riders and Trademark Law's First Sale Rule, 27 Santa Clara Computer \& High Tech. L.J. 457, 458 (2011) ("The coincidence of consumers' and trademark owners' interests may provide legitimate grounds for distinguishing trademark first sale doctrine from copyright and patent first sale doctrine.").

12. See, e.g., Impression Prods., Inc. v. Lexmark Int'l, Inc., 137 S. Ct. 1523, 1531-36 (2017) (holding that first sale overrides contractual provisions and that first sale in patent law applies to transactions abroad).

13. 17 U.S.C. $\S 109$ (a) (2018).

14. Id. § 106(1)-(2), (4), (6).

15. Id. § 106(1).

16. Id. $\S 106(2)$.

17. Id. (giving the copyright holder the exclusive right "in the case of literary, musical, dramatic, and choreographic works, pantomimes, and motion pictures and other audiovisual works, to perform the copyrighted work publicly . . . [P]ictorial, graphic, or sculptural works" are not included in the performance right).

18. See Bowman v. Monsanto Co., 569 U.S. 278, 280 (2013).

19. Ariel Katz, The First Sale Doctrine and the Economics of Post-Sale Restraints, 2014 BYU L. REv. 55, 141 (2014) ("Despite over a hundred years of adjudication, courts have never been able to draw the exact contours of the first sale doctrine or fully articulate its rationale.").

20. First sale is also related to other doctrines that may be triggered by restraints on resale. See Herbert Hovenkamp, Post-Sale Restraints and Competitive Harm: The 
someone sells a painting, one would expect an implicit agreement that the buyer could display the painting or resell it, as both actions are customary with artworks. To simplify transactions, the rights to resell and display are automatically included in the transaction. The other justification is the policy against restraints on alienation, borrowed from the law of real property. Someone who sells property may not impose unreasonable restraints on the buyer's ability to resell the property. ${ }^{21}$ As transplanted to intellectual property law, once a party voluntarily parts with a copy, she should no longer be able to control what the buyer does with it. Hence, her rights are "exhausted" in that particular copy. The underlying rationale is important for determining the extent of the first sale doctrine. If first sale is a gap-filler, then the parties could contract around it, agreeing that the property sold would not be subject to first-sale rights. ${ }^{22}$ If first sale is a policy-based bar against unreasonable restraints on alienation, then first sale is mandatory-it is not subject to the agreement of the parties but rather is the opposite: a limit on the enforceability of their agreement.

Both strains can be seen in the case law. Two recent Supreme Court cases, however, decisively rested first sale on the restraints-againstalienation rationale, expressly rejecting the proposition that parties can contract around first sale. This Article explores the implications of those cases for the boundaries of first sale, focusing on two issues. First, California's resale royalty law required that artists receive $5 \%$ of the proceeds on resale of their work. ${ }^{23}$ The Ninth Circuit held that the California statute was preempted by the first sale doctrine of federal copyright law. ${ }^{24} \mathrm{We}$ conclude that, if first sale serves to prevent unreasonable restraints on alienation, such resale royalty statutes should be valid. Rather than an unreasonable restraint on alienation, they permit resale, imposing a modest burden for a purpose entirely consonant with copyright law: rewarding authors. Second, software sellers have long avoided first sale by characterizing software sales as mere licenses, while formally retaining ownership of the software after

First Sale Doctrine in Perspective, 66 N.Y.U. AnN. Surv. Am. L. 487, 511 (2011) ("As they became more refined and technical, the developing doctrines of exhaustion, antitrust, and misuse all addressed practices thought to be anticompetitive, such as tying, but they also moved in different directions.").

21. See, e.g., Joseph William Singer, Property 281 (5th ed. 2017) ("However, the current approach emerging in the courts is to refuse to enforce restraints on alienation if they are unreasonable").

22. See, e.g., Ghosh \& Calboli, supra note 7, at 19 ("Nonetheless, the answer rests in part on the theory underlying the exhaustion doctrine. If exhaustion is understood as an implied license, then express terms in a contract or other agreement can defeat the exhaustion doctrine.").

23. The statute was similar to laws in effect in such jurisdictions as France, Germany, and Italy. See Marydale DeBor, Artists' Residual Rights in the Tangible Products of Creative Expression: A Survey of Legislation and an Analysis of the Feasibility of Implementation in the United States, 2 J.L. \& Com. 111, 130 (1982).

24. See Close v. Sotheby's, Inc., 894 F.3d 1061, 1064 (9th Cir. 2018). 
delivery to the buyer. ${ }^{25}$ Courts have enforced transactions according to the parties' contract. We conclude, however, that such transactions, which are intended to prevent resale of software, should be characterized as sales in substance, triggering first-sale rights to resell the software, overriding the contractual restraint on alienation.

\section{First Sale as Rooted in the Policy Against Restraints on Alienation}

The Supreme Court had left open the issue of the underlying policy of first sale, whether first sale was a gap-filler in the contract of the parties or rather a limit on how parties could allocate rights. The key copyright case from 1908, Bobbs-Merrill, emphasized that "[t]here is no claim in this case of contract limitation, nor license agreement controlling the subsequent sales of the book." ${ }^{26}$ In 1941, in patent, the Court simply stated first sale as self-evident:

Our decisions have uniformly recognized that the purpose of the patent law is fulfilled with respect to any particular article when the patentee has received his reward for the use of his invention by the sale of the article, and that once that purpose is realized the patent law affords no basis for restraining the use and enjoyment of the thing sold. ${ }^{27}$

The Court then took no patent first sale (also known as exhaustion) cases for decades, leaving it to the lower courts to reckon with the purposes of the doctrine.

\section{A. Early Cases}

The Court in Quanta Computer, Inc. v. LG Elecs., Inc. held that first sale applied to patents on methods as well as patents on products. $^{28}$ The Court did not address, however, whether first-sale rights could be limited by contract. Indeed, the Court did not provide guidance as to the underlying policy goals of the first sale doctrine. ${ }^{29}$ Quanta was decided in 2008 and, as the Court noted, its first decision

25. See David A. Rice, Licensing the Use of Computer Program Copies and the Copyright Act First Sale Doctrine, 30 Jurimetrics J. 157 (1990) (discussing how license agreements are used by software sellers to avoid the first sale doctrine).

26. Bobbs-Merrill Co. v. Straus, 210 U.S. 339, 350 (1908).

27. United States v. Univis Lens Co., 316 U.S. 241, 251 (1942) (citing Adams v. Burke, 21 L.Ed. 700 (1873); Keeler v. Standard Folding Bed Co., 157 U.S. 659 (1895); Motion Picture Co. v. Universal Film Co., 243 U.S. 502 (1917)).

28. Quanta Computer, Inc. v. LG Elecs., Inc., 553 U.S. 617, 628 (2008) ("Nothing in this Court's approach to patent exhaustion supports LGE's argument that method patents cannot be exhausted.").

29. Hovenkamp, supra note 20, at 492 ("The Supreme Court missed an opportunity to make the law of post-sale restraints more coherent in its recent Quanta Computer decision, where it reverted to a strict application of the first sale rule not clearly related to any policy of furthering competition or innovation.”). 
on patent exhaustion since $1942 .{ }^{30}$ In the absence of Supreme Court guidance, lower courts held that contracts could effectively limit first sale rights, such as by effectively prohibiting resale of the goods. The leading case was Mallinckrodt, Inc. v. Medipart, Inc., which held that the seller of a patented medical device (an "an apparatus for delivery of radioactive or therapeutic material in aerosol mist form to the lungs of a patient" ${ }^{\prime 31}$ ) could effectively prohibit the resale of the devices. ${ }^{32}$

The Supreme Court took up first sale again in 2013, but once again did not plumb the basis of the doctrine. The issue in Bowman v. Monsanto Co. was "whether a farmer who buys patented seeds may reproduce them through planting and harvesting without the patent holder's permission." 33 In general terms, the case raised the extent of patent exhaustion in self-replicating patented products, such as the seeds in Bowman or some software inventions. ${ }^{34}$ The Bowman Court, however, did not measure out the bounds of the judicially created patent exhaustion doctrine by fitting it to any underlying policy. ${ }^{35}$ Rather, the Court took a more formal approach, deeming that first sale by definition could only apply to the actual item sold, not future generations springing from that item. ${ }^{36}$ First sale in patent is a judicially created doctrine with few Supreme Court cases, so it seems inapt to treat it as a set rule to apply formalistically. The only policy consideration given much weight was the slippery slope argument that if second generation seeds were subject to first-sale rights, then the first sale exception could swallow the entire bundle of exclusive rights. ${ }^{37}$ Thus, Bowman passed on an opportunity to decide what the primary policy of first sale was. If first sale serves to put into effect the agreement of the parties, then it was a clear case: Monsanto sold the seeds subject to prohibitions on reuse of second-generation seeds, and so the farmer would infringe by buying and planting second-generation seeds. If first

30. Quanta Computer, 553 U.S. at 627 (citing Univis Lens Co., 316 U.S. 241).

31. Mallinckrodt Inc. v. Medipart Inc., 976 F.2d 700, 701 (Fed. Cir. 1992), abrogated by Impression Prods., Inc. v. Lexmark Int'l, Inc., 137 S. Ct. 1523 (2017).

32. Mallinckrodt Inc., 976 F.2d at 709.

33. Bowman v. Monsanto Co., 569 U.S. 278, 280 (2013).

34. See id.

35. See id. at $284-85$.

36. Id. ("Unfortunately for Bowman, that principle decides this case against him. Under the patent exhaustion doctrine, Bowman could resell the patented soybeans he purchased from the grain elevator; so too he could consume the beans himself or feed them to his animals. Monsanto, although the patent holder, would have no business interfering in those uses of Roundup Ready beans. But the exhaustion doctrine does not enable Bowman to make additional patented soybeans without Monsanto's permission (either express or implied).").

37. Id. ("But in short order, other seed companies could reproduce the product and market it to growers, thus depriving Monsanto of its monopoly. And farmers themselves need only buy the seed once, whether from Monsanto, a competitor, or (as here) a grain elevator. The grower could multiply his initial purchase, and then multiply that new creation, ad infinitum-each time profiting from the patented seed without compensating its inventor."). 
sale serves to protect against restraints on alienation, then the case raised interesting issues about the extent of that policy. One could argue that once patented seeds are sold, owners are free to use them as they please, including selling the second generation of seeds, and that buyers would therefore take them free of patent rights. The second-generation seeds were lawfully made, and so would be subject to first-sale rights, just as items made abroad are subject to first-sale rights. Or one could argue that the rationale of opposing restraints on alienation does not stretch so far-rather restraints on alienation apply only to the actual seeds sold and not to the offspring seeds. The Court in Bowman steered clear of such debates, limiting its ruling to what it characterized as a formal application of the doctrine to the particular facts in front of it, reserving for future cases the general boundaries of first sale. ${ }^{38}$

As noted above, the key case for first sale in copyright law was 1908's Bobbs-Merrill Co. v. Straus. ${ }^{39}$ In that case, a publisher of The Castaway, a novel, included a notice in each book directly after the copyright notice: "The price of this book at retail is $\$ 1$ net. No dealer is licensed to sell it at a less price, and a sale at a less price will be treated as an infringement of the copyright." 40 The Court held the restriction was not binding on future purchasers of the book:

In our view the copyright statutes, while protecting the owner of the copyright in his right to multiply and sell his production, do not create the right to impose, by notice, such as is disclosed in this case, a limitation at which the book shall be sold at retail by future purchasers, with whom there is no privity of contract. ${ }^{41}$

The copyright owner's exclusive right to sell the book did not entitle it to attach conditions to copies sold that would bind future owners of copies. ${ }^{42}$ Rather, that first sale was all the exclusive right to vend copies included: "The owner of the copyright in this case did sell copies of the book in quantities and at a price satisfactory to it. It has exercised the right to vend." 43 The Court in Bobbs-Merrill did not search for an underlying rationale for so limiting the exclusive rights of the copyright holder. Rather, it simply interpreted the right to sell under the statute to be limited to the right to sell a copy once, not to control the

38. Id. at 289 ("Our holding today is limited-addressing the situation before us, rather than every one involving a self-replicating product.").

39. See generally Bobbs-Merrill Co. v. Straus, 210 U.S. 339 (1908).

40. $I d$. at 341.

41. $I d$. at 350 .

42. Id. at 351 ("What the complainant contends for embraces not only the right to sell the copies, but to qualify the title of a future purchaser by the reservation of the right to have the remedies of the statute against an infringer because of the printed notice of its purpose so to do unless the purchaser sells at a price fixed in the notice.").

43. Id. 
future sales of that copy. ${ }^{44}$ The Court also rested on the lack of privity, leaving open the enforceability of such restrictions. ${ }^{45}$ The Court emphasized that the buyer had not agreed to any restrictions on further sale, leaving open the issue as to whether the parties could effectively limit the rights transferred: "It is not denied that one who has sold a copyrighted article, without restriction, has parted with all right to control the sale of it." ${ }^{46}$ So the case left open whether first sale rested on an implied agreement (which the parties could alter by contract) or a prohibition against restraints on alienation (which would nullify such restraints). As in patent, the Supreme Court took few copyright firstsale cases in the following decades and did not consider the underlying rationale for the doctrine. ${ }^{47}$

\section{B. Recent First Sale Developments in the Supreme Court}

\section{The Kirtsaeng Decision}

Awakening from its dogmatic slumbers, the Supreme Court more recently took a more decisive approach. In Kirtsaeng v. John Wiley \& Sons, the Court held that the first sale doctrine authorized the importation of copyrighted works that were made abroad with the authorization of the copyright owner. ${ }^{48}$ A student from Thailand, studying in the United States, noted that similar textbooks were sold at much lower prices in foreign markets. ${ }^{49} \mathrm{He}$ engaged in arbitrage, importing the books and reselling them in the United States. ${ }^{50}$ The publisher contended that books manufactured outside the United States were not subject to first sale, as they had not been lawfully made under the copyright statute (which triggers first-sale rights), but instead were beyond the scope of the United States copyright law under the principle of territoriality. ${ }^{51}$ The case triggered consideration of the relationship among the copyright owner's right of public distribution, including

44. Id. ("To add to the right of exclusive sale the authority to control all future retail sales, by a notice that such sales must be made at a fixed sum, would give a right not included in the terms of the statute, and, in our view, extend its operation, by construction, beyond its meaning, when interpreted with a view to ascertaining the legislative intent in its enactment.").

45. See Hovenkamp, supra note 20, at 498 ("As the law stood in 1908, any postsale restraint on a patented or copyrighted article that was imposed by means of a licensing restriction and enforced by an infringement action was unenforceable. However, the courts had not yet addressed the legality of restricted distribution agreements under the Sherman Act.").

46. Bobbs-Merrill, 210 U.S. at 350.

47. The Court did consider restrictions on resale in the context of antitrust, as vertical restraints. See Hovenkamp, supra note 20, at 504 ("Most decisions that have applied the rule have involved either tying arrangements or [resale price maintenance], and the Court was typically not very subtle about noting that the first sale rule and antitrust law pulled in tandem.").

48. Kirtsaeng v. John Wiley \& Sons, Inc., 568 U.S. 519, 538-39 (2013).

49. $I d$. at 527 .

50. Id.

51. Id. 
rights of importation, and the first sale doctrine's limitation on the public distribution right. ${ }^{52}$ The Court resolved the conflict in favor of first sale, holding that first sale was not limited to domestic sales or to copies made in the United States. ${ }^{53}$

Unlike in Bobbs-Merrill, the Court in Kirtsaeng did not simply address the matter by technically applying the statutory exclusive rights. Rather, the Court traced back the link between first sale and restraints on alienation historically:

The "first sale" doctrine is a common-law doctrine with an impeccable historic pedigree. In the early 17th century Lord Coke explained the common law's refusal to permit restraints on the alienation of chattels.

[If] a man be possessed of . . . a horse, or of any other chattel ... and give or sell his whole interest ... therein upon condition that the Donee or Vendee shall not alien[ate] the same, the [condition] is voi[d], because his whole interest . . . is out of him, so as he hath no possibilit[y] of a Reverter, and it is against Trade and Traffi[c], and bargaining and contracting betwee[n] man and man: and it is within the reason of our Author that it should ouster him of all power given to him."

Lord Coke's "explanation," as has been noted, is rather circular: restraints on alienation are void because they are void. ${ }^{55}$ The Court did add some economic policy to the bare statement: "With these last few words, Coke emphasizes the importance of leaving buyers of goods free to compete with each other when reselling or otherwise disposing of those goods. American law too has generally thought that competition, including freedom to resell, can work to the advantage of the consumer." 56 So the Court hinted that the rationale rested on preventing anti-competitive behavior, but did not spell out why freedom to resell goods would necessarily promote competition, rather than, for example, simply causing the seller to limit its sales. The decision, how-

52. Id. at 528 .

53. $I d$. at 525 .

54. Id. (quoting 1 E. Coke, Institutes of the Laws of England $§ 360$ (1628)); see also Charles M. Gray, Two Contributions to Coke Studies, 72 U. CHI. L. Rev. 1127, 1135 (2005).

55. See, e.g., Glen O. Robinson, Personal Property Servitudes, 71 U. CHI. L. Rev. 1449, 1481 (2004) ("Coke's locution (as well as his spelling) is archaic, yet, astoundingly, the circular style of reasoning can still be found in contemporary statements that explain that restraints on alienability are "repugnant to the deed.").

56. Id. (citing Leegin Creative Leather Prods., Inc. v. PSKS, Inc., 551 U.S. 877, 886 (2007)) (restraints with "manifestly anticompetitive effects" are per se illegal; others are subject to the rule of reason) (internal citations omitted); 1 P. ArEedA \& H. Hovenkamp, Antitrust Law 4, II 100 (3d ed. 2006) (“[T]he principal objective of antitrust policy is to maximize consumer welfare by encouraging firms to behave competitively."). 
ever, rested first sale firmly on the policy against restraints on alienation. ${ }^{57}$

The Kirtsaeng Court stated another reason that relied on the policy against restraints on alienation: "The 'first sale' doctrine also frees courts from the administrative burden of trying to enforce restrictions upon difficult-to-trace, readily movable goods." 58 The Court also placed weight on commercial practices now embedded in United States culture that depend on first sale and on the absence of restraints on alienation: "Associations of libraries, used-book dealers, technology companies, consumer-goods retailers, and museums point to various ways in which a geographical interpretation would fail to further basic constitutional copyright objectives, in particular 'promot[ing] the Progress of Science and useful Arts." 59 That suggests a broader rationale than the promotion of competition.

\section{The Lexmark Decision}

The Supreme Court's 2017 patent law decision in Impression Products v. Lexmark Int'l, Inc. hewed to Kirtsaeng and made the policy of restraints on alienation the central core of the first-sale doctrine in patent law. ${ }^{60}$ In Lexmark, purchasers of printer cartridges agreed "to use the cartridge only once and to refrain from transferring the cartridge to anyone but Lexmark." 61 The Court held that first sale cannot be limited by contract. The clause notwithstanding, it would not be patent infringement if there was further use or resale of the cartridge-although the provision might be enforceable between the parties as a matter of contract law. ${ }^{62}$ Relying on Kirtsaeng, the Lexmark Court also held that first sale applies to domestic and international sales. ${ }^{63}$ More than just a default rule subject to change by the parties, under Lexmark, first sale became a nonwaivable effect of a sale. ${ }^{64}$ Accordingly, any restrictions made in connection with the sale of a patented item may not be enforced through actions for patent infringement (there being no more patent rights in the item sold), but rather through contract alone. ${ }^{65}$ This is not merely a shift in the basis

57. Katz, supra note 19, at 123 ("The majority solved the problem by opting for international exhaustion, emphasizing the common law (rather than statutory) origin of the doctrine, and evincing strong commitment to the continuing relevance of the common law's hostility to restraints on alienation.").

58. Kirtsaeng v. John Wiley \& Sons, Inc., 568 U.S. 519, 539 (2013).

59. Id. at 540 (quoting U.S. Const. art. I, § 8, cl. 8).

60. See Impression Prods., Inc. v. Lexmark Int'l, Inc., 137 S. Ct. 1523, 1527 (2017).

61. Id. at 1525 .

62. Id. at 1526 .

63. Id.

64. Id. at 1529.

65. The court in Lexmark stated:

A patentee's authority to limit licensees does not, as the Federal Circuit thought, mean that patentees can use licenses to impose post-sale restrictions on purchasers that are enforceable through the patent laws. So long as 
for enforcing rights. Because only contract rights survive, the patent holder cannot enforce restrictions against parties using the item that are not parties to the sale, such as subsequent buyers, due to the privity requirements of contract law.

Although applying patent law ${ }^{66}$ to first sale (more often called "exhaustion" in the patent context ${ }^{67}$ ), the Lexmark Court adopted the rationale from Kirtsaeng and rested first sale on the policy against restraints on alienation:

This well-established exhaustion rule marks the point where patent rights yield to the common law principle against restraints on alienation. The Patent Act "promote[s] the progress of science and the useful arts by granting to [inventors] a limited monopoly" that allows them to "secure the financial rewards" for their inventions. But once a patentee sells an item, it has "enjoyed all the rights secured" by that limited monopoly. Because "the purpose of the patent law is fulfilled ... when the patentee has received his reward for the use of his invention," that law furnishes "no basis for restraining the use and enjoyment of the thing sold." 68

a licensee complies with the license when selling an item, the patentee has, in effect, authorized the sale. That licensee's sale is treated, for purposes of patent exhaustion, as if the patentee made the sale itself. The result: the sale exhausts the patentee's rights in that item. A license may require the licensee to impose a restriction on purchasers, like the license limiting the computer manufacturer to selling for non-commercial use by individuals. But if the licensee does so-by, perhaps, having each customer sign a contract promising not to use the computers in business-the sale nonetheless exhausts all patent rights in the item sold. The purchasers might not comply with the restriction, but the only recourse for the licensee is through contract law, just as if the patentee itself sold the item with a restriction.

Id. at $1534-35$ (citations omitted).

66. Note that first sale applies also in trademark law, but the context involves a different set of policy concerns. See Barnes, supra note 11, at 460 ("While creators and users have a co-incident interest in providing creators financial incentives to produce intellectual property, users of copyrighted expressions and patented inventions seek free access to those creations after creation. This is not entirely true of trademarks, where consumers retain an interest in a single supplier's exclusive use of a mark in order to be sure that they are getting the particular brand of goods they desire."); AuTomotive Gold Inc. v. Volkswagen of Am., Inc., 603 F.3d 1133, 1138-39 (9th Cir. 2010) ("For example, a producer may purchase non-functioning Rolex watches and refurbish them with non-Rolex parts, leaving only the original casing. Even if the producer adequately explains the nature of the refurbished watches to purchasers, the producer nonetheless infringes on Rolex's trademarks by profiting from the Rolex name. In such a case, the purchasers buy the watches in order to make others think that they have bought a true Rolex watch.") (citing Rolex Watch, U.S.A., Inc. v. Michel Co., 179 F.3d 704, 707-10 (9th Cir. 1999)). But see Sebastian Int'l, Inc. v. Longs Drug Stores Corp., 53 F.3d 1073, 1077 (9th Cir. 1995) (holding first sale applied to trademarked goods, even if possible that consumers erroneously believed reseller was affiliated with trademark owner).

67. Barnes, supra note 11, at 461 n.6. In patent law, the terms "first sale" and "patent exhaustion" are used interchangeably. See 5 Donald S. Chisum, Chisum on PATENTs § 16.03[2][a] (2005).

68. Lexmark, 137 S. Ct. at 1531-32 (quoting United States v. Univis Lens Co., 316 U.S. 241, 260 (1942); Keeler v. Standard Folding Bed Co., 157 U.S. 659, 661 (1895)). 
The Court then quoted Kirtsaeng for first sale's "impeccable historic pedigree." 69 The Court further described first sale as a "venerable principle." 70 The doctrine was rooted in:

hostility toward restraints on alienation. That enmity is reflected in the exhaustion doctrine. The patent laws do not include the right to "restrain [ ] . . further alienation" after an initial sale; such conditions have been "hateful to the law from Lord Coke's day to ours" and are "obnoxious to the public interest."

The Court then gave a modern example of Coke's pronouncement:

Take a shop that restores and sells used cars. The business works because the shop can rest assured that, so long as those bringing in the cars own them, the shop is free to repair and resell those vehicles. That smooth flow of commerce would sputter if companies that make the thousands of parts that go into a vehicle could keep their patent rights after the first sale. Those companies might, for instance, restrict resale rights and sue the shop owner for patent infringement. And even if they refrained from imposing such restrictions, the very threat of patent liability would force the shop to invest in efforts to protect itself from hidden lawsuits. ${ }^{72}$

The Court noted that in antitrust cases, it had been no defense to a charge of resale price maintenance that the goods were patented because the first sale exhausted the patent rights. ${ }^{73}$

In its second holding, the Court in Lexmark rejected the argument that the territorial nature of intellectual property limited first sale's effect to sales made within the United States. Rather, first sale applies to any sale of an authorized item, regardless of where the sale occurs. $^{74}$ The Court again rested principally on the policy against restraints on alienation:

69. Id. at 1532 (quoting Kirtsaeng v. John Wiley \& Sons, Inc., 568 U.S. 519, 538 (2013)).

70. Id.

71. Id. (quoting Straus v. Victor Talking Machine Co., 243 U.S. 490, 501 (1917)).

72. $I d$.

73. Id. at 1533 ("It is true that Boston Store and Univis involved resale price restrictions that, at the time of those decisions, violated the antitrust laws. But in both cases it was the sale of the items, rather than the illegality of the restrictions, that prevented the patentees from enforcing those resale price agreements through patent infringement suits.").

74. The Court made clear that exhaustion did not depend on a sale within the United States:

The theory behind the Government's express-reservation rule also wrongly focuses on the likely expectations of the patentee and purchaser during a sale. Exhaustion does not arise because of the parties' expectations about how sales transfer patent rights. More is at stake when it comes to patents than simply the dealings between the parties, which can be addressed through contract law. Instead, exhaustion occurs because, in a sale, the patentee elects to give up title to an item in exchange for payment. Allowing patent rights to stick remora-like to that item as it flows through the market would violate the principle against restraints on alienation. Exhaustion does not depend on whether the patentee receives a premium for selling in the 
Applying patent exhaustion to foreign sales is just as straightforward. Patent exhaustion, too, has its roots in the antipathy toward restraints on alienation, ... and nothing in the text or history of the Patent Act shows that Congress intended to confine that borderless common law principle to domestic sales. ${ }^{75}$

There is irony in the statement that nothing in the Patent Act stated otherwise-patent exhaustion is an entirely judge-made doctrine, so the Patent Act does not say anything about patent exhaustion in the first place. But the Court did make clear that its guiding principle for exhaustion was the policy against restraints on alienation. The Court noted that first sale is expressly stated in the Copyright Act, and it took that as support for following Kirtsaeng on the international exhaustion principle: [T] here is a " "historic kinship between patent law and copyright law,' and the bond between the two leaves no room for a rift on the question of international exhaustion." 76 Accordingly, a patent holder has less power to partition markets for its patented item because parties that acquire authorized items sold abroad may import them into the United States without infringing the relevant patent.

The Court repeated the idea that first sale limits the patent or copyright holder to "one bite at the apple" when selling an item: "[T]he right to exclude just ensures that the patentee receives one rewardof whatever amount the patentee deems to be 'satisfactory compensation'-for every item that passes outside the scope of the patent monopoly." ${ }^{77}$ The Court then ended with a piscine flourish: "Instead, exhaustion occurs because, in a sale, the patentee elects to give up title to an item in exchange for payment. Allowing patent rights to stick remora-like to that item as it flows through the market would violate the principle against restraints on alienation." 78 After Kirtsaeng and Lexmark, first sale rests on the policy against restraints on alienation, and so serves as a limit on contracts involving patented or copyrighted goods, not simply to fill a gap in the parties' agreement.

\section{How Broadly Does the First Sale Extend, If IT IS to Prevent Restraints on Alienation?}

First sale is not a complete ban on restraints on alienation. The firstsale doctrine in copyright provides by statute that the owner of an

United States, or the type of rights that buyers expect to receive. As a result, restrictions and location are irrelevant; what matters is the patentee's decision to make a sale.

Id. at 1538 .

75. Id. at 1536

76. Id. (quoting Sony Corp. of Am. v. Universal City Studios, Inc., 464 U.S. 417, 439 (1984)).

77. Id. at 1537 (quoting Keeler v. Standard Folding Bed Co., 157 U.S. 659, 661 (1895)).

78. Id. at 1538 . 
authorized copy may sell that copy ${ }^{79}$ or display ${ }^{80}$ that copy without infringing the copyright holder's exclusive rights to do the same. That does not mean that, once sold, a copy passes to the owner free of the relevant copyright. First sale eliminates the distribution right and the display right of the physical copy purchased ${ }^{81}$ First sale leaves in effect the other exclusive rights: to make copies, to adapt the work, and to perform the work in public. First sale also has limits keeping even the distribution right in place for some transactions. It is impermissible for the owner of a copy of a computer program or music recording to rent that copy out ${ }^{82}$ for direct or indirect commercial gain. This is to prevent businesses from providing short-term rentals to those wishing not to use the copies during rental but rather to make unauthorized copies.

Restraints on alienation have been described as a "longstanding but under-theorized concern;" 83 there is no generally accepted underlying policy for the general hostility to restraints on alienation. ${ }^{84}$ The Court's latest statements thus supply the view of the party with the most power to govern the doctrine, at least in the largely federal area of intellectual property. ${ }^{85}$ The Court has quite firmly stated that the first sale doctrine rests on the traditional common law policy against restraints on alienation. The rationale for that policy is economic: to keep property free of entanglements that could put friction in the

79. 17 U.S.C. $\S 109(a)(2018)$.

80. Id. § 109(c).

81. Specifically, that part of the display right pertaining to direct or projected displays, but not displays via other means, such as online. Id. $\S 109$ (c).

82. For example:

Notwithstanding the provisions of subsection (a), . . neither the owner of a particular phonorecord nor any person in possession of a particular copy of a computer program (including any tape, disk, or other medium embodying such program), may, for the purposes of direct or indirect commercial advantage, dispose of, or authorize the disposal of, the possession of that phonorecord or computer program (including any tape, disk, or other medium embodying such program) by rental, lease, or lending, or by any other act or practice in the nature of rental, lease, or lending.

Id. $\S 109(\mathrm{~b})(1)(\mathrm{A})$.

83. Molly Shaffer Van Houweling, The New Servitudes, 96 Geo. L.J. 885, 903 (2008).

84. See Robinson, supra note 55, at 1480 (footnote omitted) ("The common law has invalidated restraints on alienation of property from time out of mind. The pedigree of the rule may account for the paucity of reasons for it.").

85. Restraints on alienation are distinct from servitudes which restrict use of the property (and have been compared to intellectual property licensing terms which limit use of the subject matter), but do not prevent its alienation; the two are related in that both burden property, and so may increase transaction costs. See Van Houweling, supra note 83, at 903 ("Most servitudes do not directly restrain transfer. They merely limit the rights that can be acquired from any single owner. So a subsequent user who wants to reassemble property rights into a useful bundle must tackle the transaction costs involved in multiple negotiations. Often the problem is not so much restraint on alienation as restraint on acquisition: every individual property stick can be sold; the difficulty is buying a bundle that is useful to own.") (footnote omitted). 
gears of commerce. That could be interpreted several ways. First sale could be seen as minimizing transaction costs. ${ }^{86}$ As in the Lexmark example, if thousands of patent holders assert rights in the various parts of a car, a repair shop might possibly have to transact with them in order to repair the car. The opinions could also be seen as guarding against leveraging power in one market into a separate market (which can raise issues of antitrust or of patent misuse or copyright misuse). The patent holder gets paid once when the item is sold and cannot use that leverage later on in another market. ${ }^{87}$ Another economic rationale might be hostility to price discrimination. ${ }^{88}$ By extending fair use to international first sales, ${ }^{89}$ the decision prevented the rights holder from charging one price in the United States and another price overseas and using the importation right to prevent arbitrage, where an entrepreneur like Kirtsaeng might buy in a low-price jurisdiction and sell in the high-price jurisdiction, taking away sales from the copyright or patent holder.

\section{A. Common Law View of Restraints on Alienation}

The common law cases also looked to efficiency, albeit through a slightly different lens. The typical restraint on alienation case arose in

86. See id. at 902-03 ("Inefficient but transaction-cost-insulated servitudes represent a species of the anticommons problem described by Michael Heller with regard to fragmentation of property interests more generally. Servitudes divide rights in a single parcel of land among multiple owners. If it is later desirable to consolidate those rights in order to put the resource to its best use, fragmentation of the property bundle (and the transaction costs involved in re-bundling) can make consolidation difficult ....") (footnote omitted).

87. See, e.g., Péter Mezei, Copyright Exhaustion Law and Policy in the United States And the European Union 11-13 (2018) (discussing several aspects of this general policy).

88. On price discrimination in intellectual property, see generally INTELLECTUAL Property and Price Discrimination, Research HandboOK on the Economics of Intellectual Property Law (Peter Menell \& Ben Depoorter, eds., 2019); Michael Meurer, Copyright Law and Price Discrimination, 23 CARdozo L. Rev. 55 (2001); Wendy J. Gordon, Intellectual Property as Price Discrimination, 73 CHI.-Kent. L. REV. 1367, 1367-68 (1998).

89. Note that there are economic arguments in favor of permitting price discrimination. See Katz, supra note 19, at 77-78 ("The main benefits of price discrimination are suggested to be threefold: (1) it increases output, thereby ameliorating some of the inefficiencies otherwise associated with the exclusivity inherent in IP rights and benefiting consumers with lower ability to pay who would not be able to obtain the product if the seller could set only a uniform price; (2) increased output may contribute to achieving economies of scale and learning resulting in lower per-unit costs; and (3) even when output under price discrimination is lower compared to uniform pricing, the additional monopoly profit will encourage investment in $R \& D$ and innovation and contribute to dynamic efficiency. In sum, the argument for price discrimination is that it promotes allocative efficiency (i.e., leads to higher output and/ or lower costs) and dynamic efficiency (encourages innovation).") (footnotes omitted); Ghosh \& CALbOLI, supra note 7, at 38 ("The economic rationale for price discrimination is that uniform pricing leaves certain consumers excluded from the market.”). 
a quite different context than those in intellectual property cases. Restraints on alienation were disfavored, among other reasons, because they could reduce incentives for a property owner to devise more productive uses of the property. ${ }^{90}$ If a restraint on alienation prevented change in the use of property or prevented the owner from selling the improved property at an increased price, the property owner would have little incentive to put resources into making the property more productive or valuable. The same rationale applies to intellectual property. If the rightsholder is unable to enforce restraints on the use and ownership of items sold, that leaves owners free to make innovative uses or improvements that the rightsholder had not come up with. ${ }^{91}$ So the policy against restraints on alienation could be seen as a policy against transaction costs, leveraging into new markets (such as the secondary market for compatible parts, as in Lexmark), ${ }^{92}$ or against price discrimination ${ }^{93}$ (as in Kirtsaeng) or against restrictions on new uses of property-all of which could be put under the umbrella of economic efficiency.

It is worth noting that is not clear that first sale promotes any or all of these values. Rules that bar sellers from using one kind of conduct may simply channel sellers into even more inefficient behavior, rather than opening up the market. Especially in this era of complicated products, a seller that cannot rely on exclusive rights (because first sale cuts them off) or contractual restrictions (because first sale supersedes them) may turn to using technological measures.$^{94}$ If Lexmark cannot legally prevent resale of its printer cartridges, it may build the cartridges (or the printer) so that the cartridges do not work after the first use, or so that only Lexmark can refill them, or so that they trigger ominous warning if refilled by a reseller ("Warning-non-compatible ink cartridge detected"). In addition, restraints on alienation could be efficient. The Supreme Court compared them to remoras, ${ }^{95}$ fish that stick to sharks and whales. ${ }^{96}$ But remoras are not necessarily

90. See, e.g., SINGER, supra note 21, at 282 ("Allowing the current owner to sell or transfer ownership of the property grants that owner both the liberty to move and the power to obtain the economic benefits of the property by selling it and suing those assets for other endeavors.").

91. See Katherine J. Strandburg, Users as Innovators: Implications for Patent Doctrine, 79 U. Colo. L. Rev. 467, 474-78 (2008).

92. A related way to interpret that rationale is the antitrust prohibition on resale price maintenance. See Katz, supra note 19, at 142 (citing Keith N. Hylton, Antitrust Law: Economic Theory And Common Law Evolution 261 (2003)).

93. Id. at 84 ("More generally, recognizing that the welfare effect of price discrimination is ambiguous, contemporary literature believes that there is no compelling basis for antitrust law to prohibit price discrimination.").

94. See Ghosh \& CAlboli, supra note 7, at 16 ("Even if the principle of international exhaustion applies to physical goods, geoblocking can prevent resale and reuse of digital goods.").

95. Impression Prods., Inc. v. Lexmark Int'l, Inc., 137 S. Ct. 1538 (2017).

96. Remora, EnCyClOpAedia BRITTANicA, https://www.britannica.com/animal/ remora (last visited Jan. 10, 2020) [https://perma.cc/7ZLX-C25X]. 
parasites, but rather they may have symbiotic relationships with sharks and whales. ${ }^{97}$

The Court's reliance on economic factors is important. Restraints on alienation, in their historical pedigree in real property, were most often considered in cases involving real estate. ${ }^{98}$ As the concern transferred to movable property, the cases often involved commercial matters like the transferability of stock certificates. ${ }^{99}$ So how the doctrine would be considered in some areas of intellectual property, especially copyright, affecting artistic works, might bring other factors into play. ${ }^{100}$

Looking at the "historic pedigree" of the antipathy to restraints on alienation throws some light on the Court's reliance. The traditional plaints against restraints on alienation are quite different from those put forward in Lexmark:

Total restraints on the alienation of fee simple interests have consistently been ruled to be unenforceable on the grounds that the free alienation of property furthers important societal goals. Among these goals are promoting the dispersal of property so that land ownership is not concentrated in a small number of wealthy families, ensuring that resources are controlled by the current owners rather than past ones, and facilitating the transfer of property to the owner who values the resource most highly. ${ }^{101}$

Lexmark and Kirtsaeng do not stand for the proposition that first sale overcomes any and all possible restraints on alienation. Where the line might be drawn was not an issue in those cases because both were blatant, complete restraints on alienation (no resale and no importation, respectively). Were the restraints less blunt, then the question could have arisen: whether the restraints were reasonable. Here, there could be a different application to the first sale doctrine. In copyright, first sale is a statutory rule. ${ }^{102}$ Kirtsaeng simply dealt with a matter of interpretation of the statute, whether first sale's limitation on the distribution right included the importation right (which is defined as a supplement to the distribution right). In patent law, by con-

97. See id.

98. Cf. Robinson, supra note 55, at 1455 ("Thus few occasions arise for considering the validity of personal property servitudes as a matter of general common law.").

99. See, e.g., Rafe v. Hindin, 29 A.D.2d 481, 484-85, 288 N.Y.S.2d 662, 665 (App. Div. 1968) (holding that requirement for consent of other stockholder to transfer stock certificate was an "unwarrantable and unlawful restraint on the sale of personal property").

100. See Robinson, supra note 55, at 1462 ("Moving from common law property to intellectual property is a bit more difficult because of fundamental differences in the property rights regimes.").

101. Julia D. Mahoney, Perpetual Restrictions on Land and the Problem of the Future, 88 VA. L. Rev. 739, 774-75 (2002) (citing Joseph William Singer ET AL., Property Law: Rules, Policies, and Practices 572 (2d ed. 1997)).

102. See 17 U.S.C. $\$ 109$ (2018). 
trast, first sale (exhaustion) is a judicially created doctrine, ${ }^{103}$ and its scope has long been unsettled. ${ }^{104}$ Until Lexmark, the governing law under Federal Circuit precedent was that patent exhaustion was effectively a default rule, subject to rearrangement by the contract between the parties to that first sale. In the leading case, Mallinckrodt, Inc. v. Medipart, Inc., the Federal Circuit had held that restrictions in the sale of a patented medical device could be enforced as a matter of patent law against remote purchasers. ${ }^{105}$ That holding was hard to reconcile with the first sale generally, as it conflicted with the non-enforceability of similar restrictions in such cases as Bobbs-Merrill. ${ }^{106}$ Mallinckrodt was overruled by the Supreme Court in Lexmark. After Lexmark, however, the Court retained the power to define the scope of first sale in patent. Additionally, even though copyright defines first sale by statute, the Court has considerable leeway in interpreting the statute (as demonstrated in Kirtsaeng), and in deciding the extent to which first sale, as federal law, preempts contract and copyright law. Kirtsaeng looked to general principles, rather than the particular language of the copyright statute, in emphasizing the policy against restraints on alienation. ${ }^{107}$

\section{B. "Reasonableness" of Restraints on Alienation}

To accurately convey the rule and policies from the common law, the rational underlying first sale would be that unreasonable restraints on alienation are not effective. The "modern trend," as embodied in the Restatement, is that restraints on alienation are enforceable if reasonable: "A servitude that imposes a direct restraint on alienation of the burdened estate is invalid if the restraint is unreasonable. Reason-

103. First sale could also be applied judicially in state areas of intellectual property, such as the right of publicity. See Nannette Diacovo, Going Once, Going Twice, Sold: The First Sale Doctrine Defense in Right of Publicity Actions, 12 U. Miami Ent. \& Sports L. Rev. 57, 92 (1995).

104. First sale is also judicially created in trademark law, with similar questions about its scope. See Barnes, supra note 11, at 458 (discussing Au-Tomotive Gold Inc. v. Volkswagen of Am., Inc., 603 F.3d 1133, 1136 (9th Cir. 2010)) ("In May 2010, in what appears to be the first case addressing the issue, the Federal Circuit Court for the Ninth Circuit relied on the free-rider rationale to hold that the first sale rule was not an affirmative defense in trademark post-sale confusion cases.").

105. Mallinckrodt, Inc. v. Medipart, Inc., 976 F.2d 700, 708-09 (Fed. Cir. 1992), abrogated by Impression Prods., Inc. v. Lexmark Int'l, Inc., 137 S. Ct. 1523 (2017).

106. See Hovenkamp, supra note 20, at 501-02 ("The second historical exception to first sale aggressiveness occurred more recently, when the Court of Appeals for the Federal Circuit revived Justice Lurton's attempt to make the doctrine turn on realistic threats of monopoly. The Mallinckrodt case once again distinguished 'conditional' sales, which occur when the patentee places restrictions on the rights of purchasers, thus conveying away less than its entire patent interest in the article in question.") (footnote omitted).

107. Katz, supra note 19, at 123 ("The majority solved the problem by opting for international exhaustion, emphasizing the common law (rather than statutory) origin of the doctrine, and evincing strong commitment to the continuing relevance of the common law's hostility to restraints on alienation."). 
ableness is determined by weighing the utility of the restraint against the injurious consequences of enforcing the restraint."108 The Lexmark Court did not note this distinction, speaking only of the "common law's refusal to permit restraints on the alienation of chattels." 109 In Lexmark and Kirtsaeng, however, the reasonableness rule may have been irrelevant. Both dealt with direct and complete restraints on alienation: a contractual prohibition against resale in Lexmark and a bar against importation in Kirtsaeng. Reasonableness may have seemed a moot point in those cases. But if restraints on alienation are to be the key policy behind first sale, then the reasonableness of a restraint should be germane to whether a limitation is equivalent to first sale (for express preemption) and for whether it conflicts with first sale (for conflict preemption). ${ }^{110}$

The common law cases offer a spectrum of cases on the reasonableness of restraints on alienation. For example, courts have differed in the real estate area on whether due-on-sale clauses constitute an unreasonable restraint on alienation. ${ }^{111}$ Similarly, courts are divided about whether a right of first refusal is an unreasonable restraint on alienation. ${ }^{112}$ Courts look at whether the right of first refusal is reasonably geared to protect an interest of the former owner. For example, where there was a perpetual option to purchase in the event of any offer for the property, which did not protect any interest of the option holder geared to the land, the restraint was held unreasonable. ${ }^{113}$ A right to purchase a warehouse at a price well below market,

108. Restatement (Third) of Prop.: Servitudes $§ 3.4$ (Am. Law Inst. 2000).

109. Lexmark, 137 S. Ct. at 1526.

110. See Bonito Boats, Inc. v. Thunder Craft Boats, Inc., 489 U.S. 141, 168 (1989) (applying patent preemption); see also 17 U.S.C. $\$ 301$ (2018) (providing for copyright preemption of state law).

111. See Occidental Sav. \& Loan Ass'n v. Venco P'ship, 293 N.W.2d 843, 845 (Neb. 1980) ("We are somewhat at a loss to understand how or why so many courts have been willing to describe a 'due on sale' clause as a restraint on alienation and we are unwilling to do so.").

112. An unadorned right of first refusal ("ROFR") is likely enforceable, but rights of first refusal are often unreasonable where they set a below market option price or have other restrictions that interfere with market sales. R. Wilson Freyermuth, Private Transfer Fee Covenants: Cleaning Up the Mess, 45 Real Prop. Tr. \& Est. L.J. 419, 436 (2010) ("Because of their minimal impact upon alienability, nearly all classic ROFRs will satisfy the rule against unreasonable restraints on alienation.").

113. See, e.g., Laska v. Barr, 2018 S.D. 6, II 28, 907 N.W.2d 47, 55 (2018). ("The Laskas need only receive a third-party offer to trigger the Barr Partners' right to purchase the property for $\$ 10,500$ per acre, which right to purchase exists for eternity. Because there is a significant interference with the Laskas' ability to transfer the property without a strong purpose justifying the restraint, the practical effect of the restraint, if imposed, will prevent the long-term improvement and marketability of Juffer Three. The court did not err when it held that the right of first refusal is an unreasonable restraint on alienation and repugnant to the interest created."); Iglehart v. Phillips, 383 So. 2d 610, 615 (Fla. 1980) ("It is the generally accepted rule that a fixed price repurchase option of unlimited duration, independent of the lease, is an unreasonable restraint."); Mo. St. Hwy. Comm'n v. Stone, 311 S.W.2d 588 (Mo. App. 1958); 6 American Law of Property $§ \$ 26.63-.67$ (A. J. Casner ed., 1952); see also 
in the event that the warehouse was no longer used, was an invalid restraint on alienation. ${ }^{114}$ By contrast, the right to match market rate offers was held reasonable. ${ }^{115} \mathrm{~A}$ key factor is maintaining incentives to use the land productively: ${ }^{116}$ "An option for a fixed price clearly discourages any improvements of the land by the existing property owner because he could never recover the value of the improvements should the optionee exercise the option."117 A long-term option to repurchase at a fixed price deadens the incentive to make the property more valuable. ${ }^{118} \mathrm{~A}$ right of refusal at market price, by contrast, preserves the incentives to use the property productively. ${ }^{119}$

The policy against restraints on alienation rested on real property considerations:

The rule against restraints on alienation is based upon, among other things, the desirability of keeping property responsive to the current exigencies of its current beneficial owner and upon the desirability of avoiding the retardation of the natural development of a commu-

4 David A. Thomas, Thompson on Real Property $§ 2015$ (1979); 7 David A. Thomas, Thompson on Real Property $§ 3574$ (1962).

114. Procter v. Foxmeyer Drug Co., 884 S.W.2d 853, 859 (Tex. App.-Dallas 1994, no pet.) ("We conclude that $\$ 79,955.38$ is unreasonable as a matter of law to pay for real estate valued at approximately $\$ 550,000 . ")$.

115. Lorentzen v. Smith, 2000-NMCA-067, 129 N.M. 278, 283, 5 P.3d 1082, 1087 ("The contractual rights of first refusal before us in this appeal are not forfeiture restraints; they are merely preemptive provisions as described in Section 4.4 of the Restatement. Thus, they are enforceable as long as the price and timing are reasonable. The reasonableness of the price is self-evident: either matching a bona fide offer for the 52-acre tract, or offering fair market appraised value for Lot One.").

116. Camino Gardens Ass'n, Inc. v. McKim, 612 So. 2d 636, 642 (Fla. Dist. Ct. App. 1993) ("This provision reduces the incentive of mortgage lenders to finance the purchase of this property because the lender will bear the burden of providing funds and bear the risk of potential devaluation, while the Association receives all the benefits of any appreciation in the property's value. In essence, this repurchase option amounts to a right of first refusal based on a fixed price rather than the fair market value of the property. Pursuant to Inglehart [sic], such a provision is void as a matter of law.").

117. Iglehart v. Phillips, 383 So. 2d 610, 615 (Fla. 1980).

118. Cf. Randolph v. Terrell, 768 S.W.2d 736, 739 (Tex. App.-Tyler 1987, writ denied) ("In our view, the option or right of first refusal provided by the deed at hand was not reasonable in at least two respects. First, it provided that the grantors personally could repurchase the lands at any time during their lifetimes for the same consideration paid to them in 1959 by the grantee and secondly, no limit was placed on the time allowed for the actual exercise of the option.").

119. Old Port Cove Condo. Ass'n One, Inc. v. Old Port Cove Holdings, Inc., 954 So. 2d 742, 746 (Fla. Dist. Ct. App. 2007), approved, 986 So. 2d 1279 (Fla. 2008). The court held:

The option right in this case is at market value. It states: "the Association shall have the right of first refusal for the purchase of said real property upon the same terms and conditions as are proposed for its sale by [Owner]." [e.s.] Obviously from its plain text, the option is triggered only when Owner proposes to sell the property. In offering to sell, Owner could either specify a price or let buyers make the offer. Either way, it is market value that is the basis for the option.

Id. 
nity by removing property from the ordinary channels of trade and commerce. $^{120}$

In evaluating the reasonableness of a restraint, the Restatement suggests looking at whether it really restrains the seller: "The standard against which the impact of a restraint is to be measured is that of the property owner free to transfer property at his or her convenience at a price determined by the market."121

Courts and state legislatures have dealt with a restraint on alienation of real estate that is quite similar to a resale royalty right. "Private transfer fee covenants" may provide that, when real estate is sold, a percentage (usually around 1\%) will go to the original developer of the real estate, to a co-op association, or to some other party. ${ }^{122}$ Whether such restraints are reasonable is unsettled. Professor Freymuth classified them into three groups:

The first imposes a fee payable to an owners' association to fund community services, amenities, or both. The second imposes a fee payable to a nonprofit organization to fund the organization's operations or activities, which may or may not be directly or indirectly related to the ownership of the affected lot. The third imposes a fee payable to the developer for which the lot owner receives no continuing services or benefits beyond acquisition of the land. ${ }^{123}$

Until fairly recently, such fees were relatively uncommon. Because the covenants likely did not "touch and concern" the land, they were generally unenforceable. The touch and concern requirement was lopped off in the Third Restatement of Property in the year 2000, and developers and others began to use private transfer fee covenants. ${ }^{124}$ Professor Freymuth suggested that transfer fee covenants to homeowners associations would likely be reasonable, as they fund vetting of purchasers, maintenance costs, and stability of the association. ${ }^{125}$ Transfer fee covenants to non-profits to support such efforts as local conservation efforts are also likely enforceable because they would benefit the

120. 61 Am. Jur. 2D Perpetuities, Etc. $\$ 88$ (citing Venture Stores, Inc. v. Pac. Beach Co. Inc., 980 S.W.2d 176 (Mo. Ct. App. W.D. 1998); Winecellar Farm, Inc. v. Hibbard, 27 A.3d 777 (N.H. 2011)).

121. Restatement (Third) of Prop.: Servitudes $\$ 3.4 \mathrm{cmt}$. c. (Am. Law. Inst. 2019).

122. See generally Freyermuth, supra note 112.

123. Id. at 424.

124. Id. at 451 ("Under the traditional if-the-benefit-is-in-gross-the-burden-won'trun rule, a developer had little incentive to impose private transfer fee covenants. Given their analytical similarity to quarter sales, courts were unlikely to enforce such covenants against successors. In the wake of the Third Restatement, however, the use of private transfer fee covenants has accelerated. The Third Restatement appears to have encouraged the spread of such covenants by purporting to reject the traditional prophylactic rule in favor of a reasonableness standard that presumes covenants are reasonable.") (footnotes omitted).

125. Id. at 452 . 
residents, ${ }^{126}$ consistent with the general rule that charitable gifts may include restraints on alienation. ${ }^{127}$ Fees that benefit a charity with little link to the real estate would be more borderline. ${ }^{128}$ Private fee covenants that simply provided a stream of income to the original developer, on the other hand, are likely unreasonable. The greatest factor is diversion of funds away from the continuing real estate to the developer, in effect eroding the tax base. ${ }^{129}$ The argument for reasonableness is that the fee allows the initial price to be lower, as the buyer discounts the price by the future obligation to pay upon resale. But buyers are unlikely to accurately gauge the necessary discount, given the difficulty of forecasting how long they will own the property and how its price will change. ${ }^{130}$ Transfer fees may also add transaction costs, accrued in identifying who now owns the transfer fee rights (which themselves may have been transferred), figuring out how they are accounted for at closing, and dealing with possible multiple transfer fees. ${ }^{131}$

Courts are still dealing with whether private transfer fees are enforceable. ${ }^{132}$ In the meantime, state legislatures have enacted statutes largely invalidating private transfer fees (that is, transfer fees payable not to the homeowners association or to a non-profit such as a conser-

126. Id. at 426-27 ("While this fee will have an impact upon all buyers within Sunrise, the benefit to the general public (preservation of environmentally sensitive land and environmental education) and to the individual Sunrise residents (potential enhancement in the value of lots within Sunrise created by proximity and/or access to the conserved land) arguably may offset this impact.").

127. Horse Pond Fish \& Game Club, Inc. v. Cormier, 581 A.2d 478, 481 (N.H. 1990) ("In other words, an express provision or condition against alienation contained in a gift made to a charitable trust or charitable corporation may constitute a valid restraint.").

128. Freyermuth, supra note 112 , at 427 ("Because the LCHF transfer fee provides for no services or facilities benefitting owners within any development, one expects such a covenant to have only a negative impact upon the value of the affected lots. One might nevertheless defend the LCHF covenant as justified based upon its general charitable purpose and the fact that its small fee only has a de minimis effect on the land's value.").

129. Id. at 463-64 (footnote omitted) ("Finally, and most importantly, the financial benefit that a private transfer fee covenant creates for the developer comes at the public's expense. To the extent that a private transfer fee covenant is enforceable against successors, it reduces the value of the affected land. This reduction artificially decreases the ad valorem tax base of the broader public community of which the affected land is a part. Incremental sums that would have funded public goods in the local community - such as public education, policing, fire protection, streets, sewers, and other community services-instead are diverted into the pockets of private developers. Furthermore, this situation happens not by a public vote, but by private contract. Sound public policy cannot and should not permit private action, taken outside the community's democratic processes, to divert the tax base for private benefit.").

130. Id. at 457.

131. Id. at 462-63.

132. See, e.g., SINGER, supra note 21, at 285 ("Provisions that require future purchasers to pay a fee to the original grantor also may well be struck down as unreasonable restraints on alienation."). 
vation group) in some forty-three states. ${ }^{133}$ That posture leaves it somewhat difficult to assess whether, by analogy, a resale royalty right is an unreasonable restraint on alienation. If forty-three states have effectively prohibited private transfer fees, then that could be seen as a public policy determination that they are indeed unreasonable. On the other hand, the fact that states needed to enact the ban by legislation rather than by judicial interpretation suggests that under the common law, the transfer fees would not be deemed unreasonable.

Looking to the underlying policy of first sale could also help courts address boundary issues about the first sale doctrine. For example, one question is: What dispositions of a work give first sale rights? First sale applies if the work is sold, but does it apply if the work is given away, ${ }^{134}$ abandoned, ${ }^{135}$ traded, or left in a will? In copyright, first-sale rights go to the owner of an authorized copy, so all such transfers would likely convey first-sale rights. ${ }^{136}$ In patent, the doctrine is judgemade, so courts would have to decide. ${ }^{137}$ By considering the underlying policy, the decision may be made less of an all-or-nothing choice. If a copy is donated, first-sale rights will attach, but restrictions on the gift may be more likely to be deemed reasonable than restrictions on a commercially marketed item, just as restricted gifts of real estate for such charitable purposes of environmental conservation or historical preservation are more likely to survive judicial scrutiny. ${ }^{138}$

133. Private Transfer \& Development Impact Fees, Nat. Ass'N Realtors, https:// www.nar.realtor/private-transfer-development-impact-fees (last visited Oct. 28, 2019) [https://perma.cc/QW8K-5J3L].

134. See LifeScan Scotland, Ltd. v. Shasta Techs., LLC, 734 F.3d 1361, 1375 (Fed. Cir. 2013) ("At bottom, a patentee has a choice as to how to secure its reward. A patentee may 'demand[ ]' a particular price in exchange for an 'article and the invention which it embodies.' . . Alternately, a patentee may choose to give that article away for free in the hope of obtaining a future benefit, as LifeScan did here. But a patentee cannot evade patent exhaustion principles by choosing to give the article away rather than charging a particular price for it. Where a patentee unconditionally parts with ownership of an article, it cannot later complain that the approach that it chose results in an inadequate reward and that therefore ordinary principles of patent exhaustion should not apply."); Brilliance Audio, Inc. v. Haights Cross Commc'ns, Inc., 474 F.3d 365, 373 (6th Cir. 2007) (holding first sale rights apply to items given away).

135. For a paper concluding that first sale should apply to abandoned property, such as the murals by the noted pseudonymous artist Banksy, see Dan Karmel, Off the Wall: Abandonment and the First Sale Doctrine, 45 Colum. J.L. \& Soc. Probs. 353, 377 (2012) ("He had the choice of how, where, and when to release his works to the public. Perhaps most importantly, he had the choice of whether to release his works. He should not be able to subsequently place additional restrictions on what may be done with them.").

136. 17 U.S.C. $§ 109$ (a) (2018).

137. See Impression Prods., Inc. v. Lexmark Int'l, Inc., 137 S. Ct. 1523, 1536 (2017) (discussing how exhaustion is a common law doctrine applied by courts to the patent statute).

138. Cf. SINGER, supra note 21 , at 282 ("Restraints on alienation are generally allowed when the holder of the property interest is a charity."). 
Another issue of considerable practical importance is whether to recognize "digital first sale." ${ }^{139}$ If someone owns a digital copy of music or a movie, he or she might wish to sell it to someone over the internet. If he or she simply sent a copy electronically, that would likely not fit within the technical boundaries of copyright's first sale doctrine, which only apply to the copy that person owns. ${ }^{140}$ The Second Circuit recently held that first sale did not protect the operator of an online service for selling used music, even where it sought to ensure that only one party would have a copy of the music once sold. ${ }^{141}$ Economically, however, the transaction seems equivalent to selling an authorized copy, provided the seller destroys his copy. ${ }^{142}$ In sum, the common law cases on the reasonableness of restraints on alienation provide a guide toward interpreting first sale as motivated by the policy against restraints on alienation. The next Sections look at two live issues on the extent of first sale: resale royalty rights for artists and resale of software. Federal copyright law invalidates unreasonable restraints on alienation. ${ }^{143}$ Can state law require payments to artists when their works are resold? Can state contract law permit software sellers to prevent resale of software, by characterizing transactions as mere licenses, as opposed to sales?

\section{Whether First Sale Preempts Resale Royalty Rights FOR Artists}

Federal copyright law and patent law preempt state law in their respective areas. ${ }^{144}$ The extent of preemption (as with the extent of first sale) is unsettled because the Supreme Court has taken few cases on the question. The most recent intellectual property case on preemption was Bonito Boats, Inc. v. Thundercraft Boats, Inc. ${ }^{145}$ in 1989, and

139. See, e.g., MezeI, supra note 87, at 92-148 (arguing that first sale should be extended to the digital context).

140. See 17 U.S.C. $\$ 109$ (a) (2018).

141. See Capitol Records, LLC v. ReDigi Inc., 910 F.3d 649 (2d Cir. 2018), cert. denied, 139 S. Ct. 2760 (2019).

142. See id. at 658 ("In addition, even if ReDigi effectively compensated (by offsetting deletions) for the making of unauthorized reproductions in violation of the rights holder's exclusive reproduction right under $\$ 106(1)$, nonetheless ReDigi's process itself involves the making of unauthorized reproductions that infringe the exclusive reproduction right unless justified under fair use. We are not free to disregard the terms of the statute merely because the entity performing an unauthorized reproduction makes efforts to nullify its consequences by the counterbalancing destruction of the preexisting phonorecords.").

143. See Impression Prods., Inc. v. Lexmark Int'l, Inc., 137 S. Ct. 1523, 1527 (2017) (discussing how copyright's first sale doctrine is rooted in the common law principle against restraints on alienation).

144. See Bonito Boats, Inc. v. Thunder Craft Boats, Inc., 489 U.S. 141, 168 (1989) (applying patent preemption); 17 U.S.C. $\$ 301$ (2018) (preemption with respect to other laws (providing for copyright preemption of state law)).

145. Bonito Boats, 489 U.S. at 168 ("By offering patent-like protection for ideas deemed unprotected under the present federal scheme, the Florida statute conflicts 
the Supreme Court has never applied the statutory preemption provision in the Copyright Act, enacted in $1976 .{ }^{146}$

\section{A. Restraints on Alienation as Artists' Moral Rights}

Kirtsaeng and Lexmark both dealt with commercial actors attempting to leverage their intellectual property rights to control markets. ${ }^{147}$ Kirtsaeng was an attempt to maintain price discrimination between domestic and foreign markets. ${ }^{148}$ Lexmark effectively dealt with the ability to prevent aftermarket competition, as well as following Kirtsaeng with respect to international dimensions. ${ }^{149}$ The doctrine of restraints on alienation might play out differently in the context of artworks. In the realm of art, many countries have long recognized the moral rights of artists to prevent distortion of their works, to receive proper attribution of their authorship, and other protections of the author's artistic claims. ${ }^{150}$ The United States extended moral rights to a set of artists in order to join the leading international copyright

with the strong federal policy favoring free competition in ideas which do not merit patent protection. ... We therefore agree with the majority of the Florida Supreme Court that the Florida statute is preempted by the Supremacy Clause.") (internal citation and quotations omitted).

146. See David E. Shipley, Droit De Suite, Copyright's First Sale Doctrine and Preemption of State Law, 39 Hastings Comm. \& ENT. L.J. 1, 4 (2017) ("The high court has not addressed a preemption issue in the general field of intellectual property since the Bonito Boats decision in 1989, and it has never addressed a preemption issue arising under section 301 of the Copyright Act of 1976.").

147. See Kirtsaeng v. John Wiley \& Sons, Inc., 568 U.S. 519, 540 (2013); Lexmark, 137 S. Ct. at 1529.

148. Note that whether price discrimination should be prohibited is a debated question. Price discrimination may be beneficial to both sellers and buyers, by allowing transactions at a range of prices to different sorts of buyers. In addition, even where price discrimination is harmful, prohibiting it may simply channel sellers to even more harmful practices. See, e.g., Copyright Act of 1976-First Sale Doctrine-Kirtsaeng v. John Wiley \& Sons, Inc., 127 Harv. L. Rev. 348, 353 (2013) ("In this case, because copyright holders have multiple alternative avenues for circumventing the effects of the first sale doctrine, the Court's decision will primarily impact the method by which copyright holders engage in price discrimination rather than the overall magnitude of price discrimination.").

149. See Lexmark, 137 S. Ct. at 1534-37 (discussing Kirtsaeng, 568 U.S. 519).

150. "That artists have certain 'moral rights' in their work is a doctrine long recognized in civil-law countries but only recently imported into the United States." Kelley v. Chi. Park Dist., 635 F.3d 290, 296 (7th Cir. 2011). Moral rights are generally grouped into two categories: rights of attribution and rights of integrity. Carter v. Helmsley-Spear, Inc., 71 F.3d 77, 81 (2d Cir. 1995) (citing Ralph E. Lerner \& Judith Bresler, ART LAw 419-20 (1989)). "Rights of attribution" generally include the artist's right to be recognized as the author of his work, to publish anonymously and pseudonymously, to prevent attribution of his name to works he did not create, and to prevent his work from being attributed to other artists. See id. "Rights of integrity" include the artist's right to prevent the modification, mutilation, or distortion of his work, and in some cases (if the work is of recognized stature), to prevent its destruction. Id. at 81-82. 
treaty, the Berne Convention. ${ }^{151}$ The Visual Artists Rights Act of 1990 ("VARA") affords artists positive rights of attribution: "to claim authorship of that work" and "to prevent the use of his or her name as the author of any work of visual art which he or she did not create." 152 This Act also prohibits misattribution, giving the right "to prevent the use of his or her name as the author" of the work if it has been distorted or modified, if that would be "prejudicial to his or her honor or reputation." "153 The Act further provides protection to the work itself, providing the artist the right "to prevent any intentional distortion, mutilation, or other modification of that work which would be prejudicial to his or her honor or reputation, and any intentional distortion, mutilation, or modification of that work is a violation of that right."154 For some works of a particular status, there is an additional right of integrity "to prevent any destruction of a work of recognized stature, and any intentional or grossly negligent destruction of that work is a violation of that right." ${ }^{55}$ The VARA, notably, is limited to a subset of authors, giving rights only to the author of a "work of visual art,"156 which is defined in considerable detail to include a "painting, drawing, print, or sculpture, existing in a single copy, in a limited edition of 200 copies" or certain photographs, likewise limited to 200 signed copies or fewer. ${ }^{157}$ Similarly, under the California statute, the author's rights

151. See Graeme W. Austin, The Berne Convention As a Canon of Construction: Moral Rights After Dastar, 61 N.Y.U. AnN. Surv. AM. L. 111, 115 (2005) ("When the United States finally joined the Berne Convention, the first 'true' multilateral convention on copyright, in 1988, its obligations included compliance with article 6bis which, among other things, announces authors' right 'to claim authorship' to their works.") (footnotes omitted).

152. 17 U.S.C. $\$ 106$ A (2018); H.R. REP. No. 101-514, at 2 (1990), as reprinted in 1990 U.S.C.C.A.N. 6915, 6924.

153. 17 U.S.C. $\$ 106$ A.

154. $I d$.

155. Id. $\S 106 \mathrm{~A}(\mathrm{a})(3)(\mathrm{B})$.

156. Id. § $106 \mathrm{~A}$.

157. The Copyright Act defines a "work of visual art" as:

(1) a painting, drawing, print, or sculpture, existing in a single copy, in a limited edition of 200 copies or fewer that are signed and consecutively numbered by the author, or, in the case of a sculpture, in multiple cast, carved, or fabricated sculptures of 200 or fewer that are consecutively numbered by the author and bear the signature or other identifying mark of the author; or (2) a still photographic image produced for exhibition purposes only, existing in a single copy that is signed by the author, or in a limited edition of 200 copies or fewer that are signed and consecutively numbered by the author.

A work of visual art does not include-

(A)(i) any poster, map, globe, chart, technical drawing, diagram, model, applied art, motion picture or other audiovisual work, book, magazine, newspaper, periodical, data base, electronic information service, electronic publication, or similar publication;

(ii) any merchandising item or advertising, promotional, descriptive, covering, or packaging material or container;

(iii) any portion or part of any item described in clause (i) or (ii);

(B) any work made for hire; or 
are not transferable, but may be waived-in the sense only that the artist and buyer may agree that the artist will be entitled to more than $5 \%$ of future sales, which one could consider an usual meaning of the word "waiver." 158

The VARA raises the question of whether restraints on alienation would be enforceable if they served the artistic-control purposes supported by VARA instead of the market-control purposes at issue in Kirtsaeng and Lexmark. ${ }^{159}$ The VARA could be seen as a recognition of the general principle that the artistic integrity of artists may be recognized and so that agreements with respect to the integrity of artworks should be enforced. Consistent with that recognition, rights under the VARA may not be transferred-a restraint on alienation built right into the Act itself. ${ }^{160}$ One could also look at how the Court recognized the first-sale interest of "libraries, used-book dealers, technology companies, consumer-goods retailers, and museums." 161 By the same token, the Court could recognize the special reliance of artists on using agreements to structure their artistic works.

On the other hand, the VARA could also be characterized instead as a carefully limited exception to the general principles of copyright law. The rights under VARA have meticulously limited boundaries; the works to which the VARA applies are a small section of the universe of copyrighted works, and the rights are nontransferable and savable. In this view, the VARA would not support an extension of artist's right by reading another exception into the statutory first sale doctrine.

If the policy behind first sale is to prevent restraints on alienation, then the policy would not extend to bar rules that do not qualify as restraints on alienation. As courts have recognized, "not every impediment to a sale is a restraint on alienation." 162 In addition, reasonable restraints on alienation might still be effective.

(C) any work not subject to copyright protection under this title.

17 U.S.C. $\S 101$ (2018).

158. Compare CAL. CIv. Code $§ 986(a)$ (2007) with 17 U.S.C. $§ 106 A(e)$ ("Transfer And Waiver.-(1) The rights conferred by subsection (a) may not be transferred, but those rights may be waived if the author expressly agrees to such waiver in a written instrument signed by the author.").

159. But see Austin, supra note 151, at 126 (discussing preemption in intellectual property as applied by the Supreme Court) ("Indeed, the Court has recognized that some of the requirements that states may impose on the marketing of goods under such circumstances in order to avoid confusion are not preempted.").

160. 17 U.S.C. $\S 106 \mathrm{~A}(\mathrm{e})$.

161. Kirtsaeng v. John Wiley \& Sons, Inc., 568 U.S. 519, 540 (2013).

162. Occidental Sav. \& Loan Ass'n v. Venco P'ship, 293 N.W.2d 843, 845 (Neb. 1980) ("It is true that the possibility of acceleration may impede the ability of an owner to sell his property as he wishes; nonetheless, not every impediment to a sale is a restraint on alienation, let alone contrary to public policy. It is a fact that zoning restrictions, building restrictions, or public improvements may impede the sale and substantially affect the ability of an owner to realize a maximum price. Yet no one 


\section{B. Resale Royalties as Restraints on Alienation}

A case that tees up those issues is Close v. Sotheby's, in which the Ninth Circuit held that the federal Copyright Act preempted a state resale royalty act. ${ }^{163}$ Section 301 (a) of the Copyright Act states that federal law preempts all state law rights that are "equivalent" to "any of the exclusive rights within the general scope of copyright. ${ }^{164}$ The California Resale Royalties Act ("CRRA") granted artists 5\% of the proceeds in the event of resale of their artwork. ${ }^{165}$ The seller was required to pay $5 \%$ of the sale to the artist ${ }^{166}$ or, if the artist could not be located, the California Arts Council. ${ }^{167}$ The Council would attempt to locate the artist, and if unsuccessful after seven years, could use the funds to acquire art for public buildings. ${ }^{168}$ The Act applied to sales in California and sales outside California by California residents (the latter provision, however, had been held invalid as contrary to the Dormant Commerce Clause under the United States Constitution ${ }^{169}$ ). The rights were limited to "a work of fine art," defined as "an original painting, sculpture, or drawing, or an original work of art in glass."170 The CRRA did not apply to sales for less than $\$ 1,000$, or works by an artist who died before $1983 .{ }^{171}$ The right was not perpetual, rather lasting until the twentieth anniversary of the death of the artist. ${ }^{172}$ The right could not be waived, other than by an agreement to pay a greater royalty than $5 \% .{ }^{173}$

suggests that such restrictions or covenants as a class, are invalid simply because they affect the ease with which one may dispose of one's property.").

163. Close v. Sotheby's, Inc., 894 F.3d 1061, 1064 (9th Cir. 2018). For discussion of the enactment and background of the California statute, see DeBor, supra note 23.

164. 17 U.S.C. § 301(a) (2018) ("On and after January 1, 1978, all legal or equitable rights that are equivalent to any of the exclusive rights within the general scope of copyright as specified by section 106 in works of authorship that are fixed in a tangible medium of expression and come within the subject matter of copyright as specified by sections 102 and 103, whether created before or after that date and whether published or unpublished, are governed exclusively by this title. Thereafter, no person is entitled to any such right or equivalent right in any such work under the common law or statutes of any State.").

165. Close, 894 F.3d at 1064. The statute provided: "Whenever a work of fine art is sold and the seller resides in California or the sale takes place in California, the seller or the seller's agent shall pay to the artist of such work of fine art or to such artist's agent 5 percent of the amount of such sale." CAL. Civ. Code $\$$ 986(a) (West 2007). For discussion of the act generally, see DeBor, supra note 23.

166. Cal. Civ. Code $\$ 986(a)$.

167. Id. § 986(a)(2).

168. Id. § 986(a)(5).

169. In an earlier decision, the Ninth Circuit had held that the application of the statute to out-of-state sales was invalid under the Dormant Commerce Clause, but that provision was separable from the rest of the statute and so did not invalidate the entire statute. Sam Francis Found. v. Christies, Inc., 784 F.3d 1320, 1320-23 (9th Cir. 2015).

170. Cal. Civ. Code $\S 986(c)(2)$.

171. Id. § 986(a)(7), (b)(2); Sam Francis Found., 784 F.3d at 1322.

172. CAl. Civ. Code $\$ 986(a)(7)$.

173. Id. § 986(a). 
The Ninth Circuit held that the California statute was preempted on the grounds that it conflicted with copyright law's first sale doctrine:

Although the CRRA's resale royalty right and § 106(3)'s distribution right are not coextensive, they are equivalent. The two rights differ in that one grants artists the right to receive a percentage payment on all sales of artwork after the first, while the other grants artists the right to receive full payment on the first (and only the first) sale. But, at root, both concern the distribution of copies of artwork and define artists' right (or lack thereof) to payment on downstream sales of those copies. ${ }^{174}$

The court ultimately relied on the policy against restraints on alienation, as in Kirtsaeng and Lexmark:

The CRRA expands the federal distribution right because, whereas the first sale doctrine limits artists' right to payment to the first sale, the CRRA grants artists an unwaivable right to a 5\% royalty on all downstream sales. See Cal. Civ. Code § 986(a). Indeed, the CRRA is designed precisely to alter the first sale doctrine by affording artists a right to at least some measure of payment on every sale after the first. At the same time, the CRRA also restricts the federal distribution right by forbidding artists from fully alienating copies of their artwork. In effect, the CRRA creates an inalienable restraint on alienation. ${ }^{175}$

Note that the restraint in Close was of a much different nature than in Kirtsaeng and Lexmark. In Kirtsaeng, the copyright holder argued that the distribution right should prevent the owner of a copy, which had been made with permission of the copyright holder, from importing it into the United States. ${ }^{176}$ In Lexmark, the copyright holder argued that the owner of a printer cartridge, who had purchased it from the original buyer, was restrained from alienating that printer cartridge because the original buyer had agreed not to resell it. ${ }^{177}$ In both cases, the intellectual property holder was seeking to prevent the party from transferring ownership of the property. ${ }^{178}$ In Close, by contrast, the resale royalty right only came into effect if the party was able to alienate the artwork. ${ }^{179}$ If the party resold an artwork, they then became obliged to remit $5 \%$ of the sale proceeds to the artist. ${ }^{180}$ The question would then become whether that rule, which is not a prohibition but rather sort of private tax, is an unreasonable restraint on alienation.

174. Close v. Sotheby's, Inc., 894 F.3d 1061, 1070 (9th Cir. 2018).

175. Id. at 1071 .

176. See Kirtsaeng v. John Wiley \& Sons, Inc., 568 U.S. 519, 526-27 (2013).

177. See Impression Prods., Inc. v. Lexmark Int'l, Inc., 137 S. Ct. 1523, 1525 (2017).

178. See id.; Kirtsaeng, 568 U.S. at 526-27.

179. Close, 894 F.3d at 1070.

180. Id. 
Ironically, fine artists depend little on copyright; buyers are not interested in copies. ${ }^{181}$ If copyright law preempts state law giving rights to artists, such as resale royalty rights, then on balance copyright may be a net loss for them. ${ }^{182}$ Viewed broadly, the Copyright Act itself is a variety of restraints on alienation. The Act makes quite clear that a physical copy of a work is separate from the copyright in the work, and the copy may be sold and resold without selling the copyright. ${ }^{183}$

The Ninth Circuit rejected the distinction between requiring payment on resale and prohibiting resale: "Even though there are differences in how the CRRA and $\S 106(3)$ affect artists' right to payment-one requires a royalty on all sales after the first, and the other contemplates full alienation upon the first sale-there is significant overlap between the two for the reasons explained above." 184 That all-or-nothing view of first sale seems to prove too much. An artist could certainly lease the copy, and retain ownership, meaning that first sale does not require that all the payment be made at once. Likewise, the property could be sold on credit, with the property itself serving as collateral, in which case payments would be spread out over time. ${ }^{185}$ If payments were not made, the artist could repossess the artwork, a powerful restraint on alienation.

The Close court also had to contend with some contrary legislative history, a subsequent House Report stating in clear terms: "For example, the law will not preempt a cause of action for a misattribution of a reproduction of a work of visual art or for a violation of a right to a resale royalty." 186 The court simply declined to recognize the statement as persuasive authority, on the grounds that it came long after the Act was passed and "at best, represent[ed] the House's under-

181. See Laura A. Heymann, Copyright and the Single Work, Jotwell (Nov. 28, 2018) (discussing Amy Adler, Why Art Does Not Need Copyright, 86 Geo. WAsh. L. REv. 313 (2018)) (Fine artists generally "have little to no desire to sell multiple copies of their work, and the number of artists who can count on licensing their work for derivative uses (museum postcards or calendars, for example) is few."); see also Brian Frye, Andy Warhol's Pantry, 8 Akron Intell. Prop. J. 17 (2015).

182. See generally Heymann, supra note 181.

183. See 17 U.S.C. $§ 202$ (2018) ("Ownership of a copyright, or of any of the exclusive rights under a copyright, is distinct from ownership of any material object in which the work is embodied. Transfer of ownership of any material object, including the copy or phonorecord in which the work is first fixed, does not of itself convey any rights in the copyrighted work embodied in the object; nor, in the absence of an agreement, does transfer of ownership of a copyright or of any exclusive rights under a copyright convey property rights in any material object.").

184. Close, 894 F.3d at 1071.

185. A "transfer of copyright" is defined to include hypothecation, meaning using the copyright as collateral. See 17 U.S.C. $\$ 202$ ("A 'transfer of copyright ownership' is an assignment, mortgage, exclusive license, or any other conveyance, alienation, or hypothecation of a copyright or of any of the exclusive rights comprised in a copyright, whether or not it is limited in time or place of effect, but not including a nonexclusive license.").

186. Close, 894 F.3d at 1072 (citing H.R. REP. No. 101-514, reprinted in 1990 U.S.C.C.A.N. 6915, 6931 (1990)). 
standing — right or wrong — of how existing law might intersect with the changes proposed in VARA."187

In addition, the Ninth Circuit, in the 1980 case of Morseburg $v$. Balyon, had long ago held that the CRRA was not preempted by the 1909 Copyright Act because it did not conflict with the Act: "A resale royalty is not provided by the 1909 Act; no hostility toward such a royalty is expressed by the Act; and, on the facts before us, the obligation to pay a resale royalty does not impermissibly restrict resales by the owners of works of fine art." 188 Close first held that Morseburg was simply irrelevant to its analysis of express preemption under the 1976 Act because Morseburg dealt with implicit conflict preemption under the 1909 Act. ${ }^{189}$ Although Morseburg was indeed decided under a different version of the Copyright Act, its holding that the CRRA did not "impermissibly restrict" 190 resales could be relevant to whether the CRRA impermissibly restricted the first sale right to resell copies.

The court in Close noted that preemption under the 1909 Act might be a live issue, to the extent sales fell between the CRRA's effective date, January 1, 1977, and the 1976 Act's effective date, January 1, 1978. ${ }^{191}$ The court cast some doubt on its earlier holding but declined ruling on the issue, rather remanding the case to see if there were any sales during that period that were still at issue in the case. ${ }^{192}$ The court also declined to rule on the issue of whether CRRA represented an unconstitutional taking. ${ }^{193}$ Although signaling that CRRA seemed similar to other restrictions that had been held permissible, the court did not decide the question, as it had been made moot by defendant's successful copyright preemption attack. ${ }^{194}$

187. $I d$.

188. Morseburg v. Balyon, 621 F.2d 972, 978 (9th Cir. 1980); see also DeBor, supra note 23 .

189. Close, 894 F.3d at 1072 ("Furthermore, our reasoning in Morseburg derived from the Supreme Court's decision in Goldstein, and that case was grounded in a different era of federal copyright law, before the Copyright Act even had an express preemption provision. Morseburg did not pretend to speak to the preemptive effect of the 1976 Act and does not control our express preemption analysis here.").

190. Morseburg, 621 F.2d at 978.

191. Close, 894 F.3d at 1074.

192. Id. ("In sum, Morseburg's reasoning would be suspect today, but it is not clearly irreconcilable with intervening higher authority. It therefore controls our analysis of plaintiffs' claims arising under the 1909 Act. We conclude that plaintiffs' claims concerning sales occurring between the CRRA's effective date of January 1, 1977, and the 1976 Act's effective date of January 1, 1978 are not preempted. On remand, the district court should determine if any of plaintiffs' claims arise between January 1, 1977, and December 31, 1977.").

193. Id. at 1075 .

194. Id. ("In some respects at least, the droit de suite resembles legislation imposing rent control, setting a minimum wage, or requiring a zoning permit. All of these measures impose real economic costs on people or businesses and may result in a wealth transfer to someone else, but they are not, for that reason alone, a governmental taking."). 
An initial question unexamined by the court in Close would be whether the resale royalty right even constitutes a restraint on alienation as opposed to a servitude of some sort. ${ }^{195}$ As defined by the Third Restatement of Property, "Direct restraints include absolute prohibitions on some or all types of transfers, including leases, prohibitions on transfer without the consent of another, prohibitions on transfer to particular persons, requirements of transfer to particular persons, options to purchase land, and rights of first refusal."196 There is a good argument that the CRRA resale royalty right is only an indirect restraint on alienation, one permitting alienation but "reducing the amount the owner might otherwise realize on a sale of the property." 197 The Third Restatement of Property would uphold such restrictions unless irrational, but many courts have stuck with the more demanding standard of reasonableness. ${ }^{198}$

But even assuming the resale royalty right qualifies as a restraint on alienation, the question remains whether it is a reasonable restraint. The economic policies against restraints on alienation (transaction costs, price discrimination, and leveraging intellectual property rights into another market) in the Lexmark opinion would not seem to apply with great force to the CRRA resale right. In a sense, transaction costs would not be directly affected. Unlike other settings where it would be necessary to negotiate with the rights-holders, the CRRA freely permits resales. So there would not be transaction costs in the sense of Lexmark-those "remoras" sticking to the item as it flows through the market ${ }^{199}$ - where it might be necessary to negotiate with a rights-holder before selling the property-or to negotiate with many rights-holders before selling some property. The $5 \%$ resale royalty, however, could be seen as a transaction cost in more general terms, similar to a tax. If sellers must pay $5 \%$ of sales to artists, then there could be fewer sales of fine art-or at any rate fewer sales of fine art in California. But those sorts of transaction costs would not seem to make the resale right "equivalent" to the copyright exclusive right of public distribution. However, the existence of the $5 \%$ resale royalty right could lead owners to sell the works in other states-outside the

195. Cf. Van Houweling, supra note 83.

196. Restatement (Third) of Prop.: Servitudes $§ 3.4$ (Am. Law Inst. 2000).

197. Id. § 3.5 ("Many servitudes indirectly affect the alienability of property by limiting the numbers of potential buyers or by reducing the amount the owner might otherwise realize on a sale of the property. If the servitude is validly created under Chapter 2, and is not otherwise invalid under the rules stated in this Chapter, the fact that the servitude results in some diminution in return to the owner, or some reduction in the potential market for the property, is not sufficient justification for refusing to give effect to the intent of the parties to create the servitude.").

198. See generally Singer, supra note 21, at 285 ("Provisions that require future purchasers to pay a fee to the original grantor also may well be struck down as unreasonable restraints on alienation.").

199. Impression Prods., Inc. v. Lexmark Int'l, Inc., 137 S. Ct. 1523, 1538 (2017). 
reach of CRRA - which could certainly entail more transaction costs, in a broad sense. ${ }^{200}$

The fact that the $5 \%$ goes to the artist rather than the state does tend to make the resale right a little more like the copyright holder's exclusive right of distribution. Although the artist does not have the right to prevent others from distributing the work (as under copyright), the artist maintains leverage to demand 5\% if the work is sold. That does give the artist some control over distribution of authorized copies.

With respect to price discrimination, that would hardly seem to be a factor with the resale right. An artist might engage in price discrimination, perhaps by making works that were deemed as special for highend buyers and more mundane works for a lower price. The resale right would hardly facilitate that. The statute could result in a mode of price discrimination, whereby the artist arranged to sell works out of state (or create them out of state) in order to avoid CRRA, which might encourage some buyers to pay more. Likewise, the artist might even create some works in categories not covered by CRRA, so that buyers would not be subject to the resale royalty obligation. But that would not allow the artist to profit from price discrimination in the way that a seller who sells the same product to different buyers at different prices can.

In that vein, a key distinction between the resale royalty right and the restraints in Kirtsaeng and Lexmark is that the resale royalty right applies to the original artwork, not copies. ${ }^{201}$ The restraint in Kirtsaeng would have allowed the publisher to sell copies of the book at one price in the United States and another price in other markets, with no fear that books could move from one market to the other. The restraint in Lexmark would have allowed the patent holder to control the market for refurbished printer cartridges. The resale royalty right applies not to an entire market of paintings, but to individual paintings. Indeed, the entire question springs from the fact that the Copyright Act defines "copy" to include the original work. ${ }^{202}$ Unlike other authors, painters do not make an original and then sell as many copies as they can. Rather, they make the original and sell it, meaning any appreciation in value goes to the subsequent owner, not the original author. The resale royalty is a modest attempt to preserve some of

200. See DeBor, supra note 23, at 128-29 (discussing how implementation of resale rights in Paris caused dealers to move sales to London).

201. First sale applies to the original and to copies, because the Copyright Act defines "copy" to include the original. 17 U.S.C. \$ 101 (2018) ("Copies" are material objects, other than phonorecords, in which a work is fixed by any method now known or later developed, and from which the work can be perceived, reproduced, or otherwise communicated, either directly or with the aid of a machine or device. The term "copies" includes the material object, other than a phonorecord, in which the work is first fixed.") (emphasis added).

202. Id. 
that value for the original artist. ${ }^{203}$ The ability of an artist to engage in price discrimination, as in Kirtsaeng, is very limited. A painter could sell his or her best work at a certain price, and also produce lowerquality works for lower prices (or sell both paintings and sketches, or sculptures and miniatures), but such practices would have limited market effect, and could easily harm the reputation of the artist.

Likewise, the CRRA resale royalty right would not permit artists to extend their rights in the artwork to other markets. In theory, a seller could bundle a CRRA-protected artwork with other merchandise and then apportion the price in a way to minimize the CRRA payment due. But that would not give the seller any market power in the market for the second item. Rather, it would simply be a matter of CRRA compliance. So it could be lumped into a broad conception of "transaction costs," in the sense of costs that might be incurred to avoid the CRRA obligations.

Looking to the policy of courts in restraint on alienation cases, the resale royalty again seems less like a restraint on alienation. Courts are concerned with whether the prohibition has real force as preventing further transfers of the property. A 5\% resale royalty right would provide a little friction, but relatively small. Read broadly, Close would conflict with the sales tax effective in most states. In many states, if an artwork is sold, the seller is obliged to remit a percentage to the state or local authorities. Sales taxes often exceed $5 \% .{ }^{204}$ It seems unlikely that courts would hold that the federal copyright and patent statutes preempt the various state sales taxes. So the restraint on alienation must somehow rest upon the fact that the $5 \%$ is owed not to the state, but rather to the artist.

If the resale royalty is deemed a restraint on alienation, albeit a rather mild one, the question then becomes how that fits into the preemption analysis. Lexmark and Kirtsaeng did not concern preemption but rather the extent of first sale itself. Those cases considered the policy of restraints on alienation as being an underlying policy of first sale. In the preemption analysis, a court could consider again restraint on alienation as the policy behind first sale, but then use that for a different question: whether the state law at issue is equivalent to, or conflicts with, federal copyright's right of public distribution, as lim-

203. See Shipley, supra note 146, at 6 ("Over time, as an artist's reputation grows and his or her works appreciate in value, the person who stands to gain from subsequent sales of those appreciated paintings and sculptural works is the collector, not the visual artist who created the work. Resale royalty laws address this disparity in how copyright law protects and rewards visual artists compared to authors, composers and other creators. Hence, droit de suite can be justified as compensation for the lack of a marketable reproduction right for many works of fine art.").

204. For example, the sales tax in Cook County, Illinois, for General Merchandise is $6.25 \%$. See What is the Sales Tax Rate in Illinois?, ILL. Revenue, https://www2.illi nois.gov/rev/questionsandanswers/Pages/139.aspx (last visited Oct. 24, 2019) [https:// perma.cc/V52Y-CUWR]. 
ited by the first sale doctrine. ${ }^{205}$ Lexmark and Kirtsaeng interpreted the first sale doctrine broadly, in order to limit the restraints on alienation in those cases. ${ }^{206}$ That does not mean that the cases stand for the proposition that all restraints on alienation are contrary to the first sale doctrine, and so should be preempted. That would be true only if, under Lexmark, all restraints on alienation were subject to the first sale doctrine. But such a broad preemptive effect of the Copyright Act would disturb commercial practices immensely. Using property as collateral is, in the very broad sense, a restraint on alienation, because the debtor cannot now sell the property free and clear of the security interest, without paying off the creditor. ${ }^{207}$ Leases are inherently restraints on alienation where property is delivered but the possessor has only the rights under the lease, and cannot further transfer the property away. Many other examples come to mind readily.

In addition, if state legislation is the guide, then California's act in legislating the resale royalty act would seem to support its reasonableness. Lastly, we must acknowledge the irony that a state statute would be preempted under state law on the theory that the rule provided by the state law was unreasonable under state law. A resale royalty right is much less restrictive, for example, than a due-on-sale clause. Such a clause provides that if collateral is sold before the loan is paid off, the entire amount of the loan becomes due. ${ }^{208}$

The resale royalty right is quite distinguishable from the resale price minimum set by the publisher in Bobbs-Merrill. First, the resale right is $5 \%$ of sales, so the owner is free to sell at whatever price she chooses. A resale minimum, by contrast, prevents any sale below the copyright owner's chosen price, which leaves control of the market for the item in the hands of the copyright owner. Second, the 5\% royalty is set by the state for all artworks. That means that the copyright owner exercises no control, and also means that, because other works

205. See Bonito Boats, Inc. v. Thunder Craft Boats, Inc., 489 U.S. 141, 168 (1989) (applying patent preemption); 17 U.S.C. $\$ 301$ (2018) (providing for copyright preemption of state law).

206. See Impression Prods., Inc. v. Lexmark Int'l, Inc., 137 S. Ct. 1523, 1536-37 (2017); Kirtsaeng v. John Wiley \& Sons, Inc., 568 U.S. 519, 538-39 (2013).

207. See U.C.C. $\S \S 9-610,615$ (Am. Law Inst. \& Unif. LaW Comm'N, amended 1998).

208. See, e.g., Occidental Sav. \& Loan Ass'n. v. Venco P'ship, 293 N.W.2d 843, 844 (Neb. 1980) ("While 'due on sale' clauses take a number of forms, essentially they are, in form, similar to the clause involved in the instant case, which provided ' $[\mathrm{I}] \mathrm{n}$ the event of a sale of said premises without the written approval of said [lender], then the whole indebtedness hereby secured shall, at the option of said [lender], immediately become due and collectible without further notice, and this mortgage may then be foreclosed to recover the amount due on said note or obligation ...." "). However, the court in that case did not hold the due on sale clause to be invalid: "We must find, as a matter of law, that 'due on sale' clauses are neither direct nor indirect restraints on alienation and, therefore, are not void as such." Id. at 848 . 
are subject to the same $5 \%$ resale royalty, sellers in that market will not be at a competitive disadvantage. ${ }^{209}$

One could argue that the resale royalty is similar to a private transfer fee, which commentators have argued would be an unreasonable restraint on alienation. ${ }^{210}$ There are also distinctions to be made between the resale royalty right and the private transfer fee. One could argue that the resale right is a little like the fee to a homeowner's association rather than a pure private fee to the original developer. The argument that the right facilitates the creation of works and their original sale is much stronger. A developer presumably will seek to sell the property at a market rate, perhaps discounted by the future transfer obligation. The developer then shares in the general real estate market's rise in price (if any). An artist likewise may sell at a market rate, but a much different sort of market. The new, unknown artist will likely get low prices and could reasonably hold on to the artworks in the hope that in the future their price will increase, independent of the increase in the price of art generally. The payments to the artist help the artist continue his career producing more art in his oeuvre. In short, the public policy of encouraging artists at the beginning of their careers seems stronger than the likelihood that private transfer fees will realistically make real estate development and sales less pricey.

The resale royalty right is closer to the sort of restraints on alienation that courts have upheld as reasonable. The right does not prevent alienation but rather imposes a $5 \%$ fee on resale. The fee itself does not obstruct resale in the way that a right of refusal or option to repurchase at a below market rate would. Rather, the fee depends on there being a sale at the market rate. The right also serves a purpose aligned with copyright, providing an incentive to creators. In the same vein, the right is analogous to purposes underlying restraints that have been held valid, because it serves to protect the interests of artists who may sell their work early in their career. The artist is far from the rightsholders in Kirtsaeng and Lexmark, who sought to leverage their rights into control over a separate market. ${ }^{211}$ Finally, the resale royalty right

209. The contrary view would be that any restriction on resale is contrary to first sale. See Shipley, supra note 146, at 22 ("Subsequent rulings have said that this freedom includes the right to resell the goods for whatever price the buyer deems appropriate, without regard to the wishes of the copyright holder. The law is at odds with these principles because it gives California artists an advantage not enjoyed by other artists, and it disadvantages California art dealers against those outside the state. Copyright owners cannot use their rights to fix resale prices in downstream markets.").

210. Amy Kathleen Lewis, Comment, Developing Disaster: How Developers Are Using a Covenant to Steal from Homeowners and Why the States Should Stop Them, 64 OKLA. L. REv. 377, 386-87 (2012).

211. Shipley, supra note 146 , at 27 . Because a $5 \%$ royalty is minimal control as compared to the $100 \%$ prohibitions in Kirtsaeng and Lexmark, those cases are distinguishable. For the view that the resale royalty is sufficient control to conflict with first sale, see id. ("In addition, as discussed in connection with conflict preemption under 
was not a product of a rights holder including restrictive language in a contract. Rather, it was a statute enacted by the state of California for policy reasons. The common law rule against unreasonable restraints on alienation is largely state law. ${ }^{212}$ It would be difficult to say that under California property law, the resale royalty statute itself was an unreasonable restraint on alienation.

The fact that the resale royalty is a general requirement under state law rather than one created by a particular artist also would weigh in favor of reasonableness. As noted above, it indicates that the state deemed the policy reasonable, and reasonableness of restraints on property is a classic state law issue. In addition, the state-created nature of the right greatly reduces a great problem with restraints on personal property. If the transferor of real estate creates a restraint on real property, it will generally be in the deed of transfer, which will be recorded in the real estate records, putting future transferees on notice. ${ }^{213}$ But the transfer of personal property generally does not require recording of an instrument (with such exceptions as automobile titles or UCC filings to perfect a security interest in personal property). ${ }^{214}$ Future transferees of personal property may not be on notice. ${ }^{215}$ In addition, if restraints were generally permitted, potential transferees might expend considerable research before acquiring property to check if it was subject to restraints, increasing transaction costs. But a state-created resale royalty right for artwork does not suffer from such a notice problem. Merchants in the California art market should be readily aware of such a requirement, just as they would be expected to know of any applicable sales tax. The resale royalty right, even if it barely qualifies as restraint on alienation, should be deemed reasonable and so not run afoul of the first sale doctrine.

\section{IV. "Licenses" to Avoid First Sale, as Restraints on Alienation}

The first sale doctrine permits the owner of a piece of property to sell it, even if the property embodies a copyrighted work or a patented invention. Copyright and patent owners in some industries have attempted to distribute products while avoiding first sale rights in order

the Supremacy Clause, recent Supreme Court decisions hold that the first sale doctrine as codified in section 109(a), not only governs, but also forbids, efforts to control downstream sales.") (footnote omitted).

212. See, e.g., Singer, supra note 21 , at 278-83 (discussing common law development using cases applying state law).

213. See, e.g., id. at 528-54 (discussing deeds and recording statutes).

214. See U.C.C. § 2-401(1) (Am. Law Inst. \& UnIf. Law Comm'n 1998) ("Subject to these provisions and to the provisions of the Article on Secured Transactions (Article 9), title to goods passes from the seller to the buyer in any manner and on any conditions explicitly agreed on by the parties.").

215. See generally Peter Menell \& Michael Meurer, Notice Failure and Notice Externalities, 5 J. Legal Analysis 1 (2013). 
to control the secondary market for the product. Software transactions are often characterized as licenses, rather than sales, in order to avoid first sale. A software company will, for a price, deliver a copy of software. ${ }^{216}$ The contract will provide that the copy of software remains the property of the software maker and is delivered subject to the terms of a license. ${ }^{217}$ The license allows the purchaser to possess and use the software but imposes restrictions. ${ }^{218}$ Most importantly, the purchaser will not have the right to resell the software. ${ }^{219}$ Courts have enforced the parties' agreements according to their terms, meaning that those copies are not subject to first sale. This Section reexamines this reasoning in the light of Kirtsaeng and Lexmark.

\section{A. Vernor v. Autodesk, Inc. and its Aftermath}

The leading case discussing the difference between software licensing and sales is Vernor v. Autodesk, Inc. ${ }^{220}$ Vernor bought copies of AutoCAD software-sophisticated computer-aided design softwarefrom parties that had acquired the software from Autodesk. ${ }^{221}$ Vernor resold the software on eBay. ${ }^{222}$ The question was whether first sale authorized him to resell the software, or whether he was infringing Autodesk's right to distribute copies of its copyrighted work to the public. Autodesk distributed the software under a licensing agreement, which provided among other things that the copy of the software remained the property of Autodesk and could not be resold. $^{223}$

The Vernor court, drawing from earlier cases, formulated a threepart analysis: "First, we consider whether the copyright owner specifies that a user is granted a license. Second, we consider whether the copyright owner significantly restricts the user's ability to transfer the software. Finally, we consider whether the copyright owner imposes notable use restrictions." 224 Under this approach, the court held the transaction to be merely a license, not a sale. First, the agreement was

216. See, e.g., Vernor v. Autodesk, Inc., 621 F.3d 1102, 1104 (9th Cir. 2010).

217. Id. ("The SLA for Release 14 first recites that Autodesk retains title to all copies. Second, it states that the customer has a nonexclusive and nontransferable license to use Release 14. Third, it imposes transfer restrictions, prohibiting customers from renting, leasing, or transferring the software without Autodesk's prior consent and from electronically or physically transferring the software out of the Western Hemisphere. Fourth, it imposes significant use restrictions.”).

218. Id.

219. Id. ("Third, it imposes transfer restrictions, prohibiting customers from renting, leasing, or transferring the software without Autodesk's prior consent and from electronically or physically transferring the software out of the Western Hemisphere.").

220. See id.

221. Id. at 1105 .

222. Id.

223. Id. at 1104 .

224. Id. at $1110-11$. 
clearly labelled a license, as opposed to a sale. ${ }^{225}$ Second, in the court's view, there were significant restrictions on transfer: transfer was prohibited. ${ }^{226}$ Third, the court held there were notable use restrictions: "The SLA also imposed use restrictions against the use of the software outside the Western Hemisphere and against modifying, translating, or reverse-engineering the software, removing any proprietary marks from the software or documentation, or defeating any copy protection." 227 Accordingly, because Autodesk reserved title in the parties' agreement, the court held that its customers were mere licensees who did not become owners of the software, meaning that Vernor did not become an owner of an authorized copy of the software, and first sale did not authorize resale by Vernor. ${ }^{228}$

Other courts have followed Vernor. ${ }^{229}$ Indeed, courts have enforced such terms so enthusiastically that only extreme attempts by copyright holders to condition transfer of copies have been invalidated. In $U M G$ Recordings, Inc. v. Augusto ${ }^{230}$ the restrictions on further transfer were not in a browsewrap or clickwrap agreement, or even obtained for consideration. Rather, a music publisher gave away promotion CDs of music, bearing the following "promotional statement":

This CD is the property of the record company and is licensed to the intended recipient for personal use only. Acceptance of this CD shall constitute an agreement to comply with the terms of the license. Resale or transfer of possession is not allowed and may be punishable under federal and state laws. ${ }^{231}$

Unlike Vernor, the Augusto court held the restriction did not prevent the passing of title to the recipients. ${ }^{232}$ Accordingly, as owners of authorized copies, they were entitled to sell them under first sale. ${ }^{233} \mathrm{Au}$ -

\section{Id. at 1111.}

226. Id. ("Autodesk retained title to the software and imposed significant transfer restrictions: it stated that the license is nontransferable, the software could not be transferred or leased without Autodesk's written consent, and the software could not be transferred outside the Western Hemisphere.").

227. Id.

228. Id. at 1111-12 ("Thus, because Autodesk reserved title to Release 14 copies and imposed significant transfer and use restrictions, we conclude that its customers are licensees of their copies of Release 14 rather than owners. Both CTA's and Vernor's sales infringed Autodesk's exclusive right to distribute copies of its work.").

229. Stephen McIntyre, Game Over for First Sale, 29 Berkeley TeCH. L.J. 1, 18 (2014) (citing cases) ("The Ninth Circuit has been especially prolific in articulating how copyright owners can avoid the pitfall of actually selling goods to their customers.").

230. UMG Recordings, Inc. v. Augusto, 628 F.3d 1175, 1180 (9th Cir. 2011).

231. Id. at $1177-78$.

232. Id. at 1183.

233. Id. at 1180 ("We conclude that, under all the circumstances of the CDs' distribution, the recipients were entitled to use or dispose of them in any manner they saw fit, and UMG did not enter a license agreement for the CDs with the recipients. Accordingly, UMG transferred title to the particular copies of its promotional CDs and cannot maintain an infringement action against Augusto for his subsequent sale of those copies."). 
gusto, however, did not question the enforceability of clauses that limit transfer of title and restrict further transfer. ${ }^{234}$ Rather, Augusto simply held that the recipients had not agreed to such clauses, ${ }^{235}$ in contrast to software cases, where the users had ordered and paid for the software and agreed to the terms. ${ }^{236}$

\section{B. Application of Vernor in Restraints on Alienation Context}

The Vernor decision gives effect to the agreement between the parties and cannot be faulted as a matter of contract law. ${ }^{237}$ Kirtsaeng and Lexmark, however, provide that federal copyright law will override inconsistent contract law in order to prevent contractual restraints on alienation from interfering with the first sale doctrine. ${ }^{238}$ Now that the policy against restraints on alienation is the key to first sale, Vernor's framework bears reexamination. The three-part test gives effect to the parties' agreement, but would be inapt under restraint against alienation scrutiny.

The first step, whether the copyright owner specifies that a user is granted a license, would be of no weight. Unreasonable restraints on alienation are not enforceable, regardless of how the parties characterize them. Indeed, a contract will rarely have a clause entitled "restraint on alienation." Rather, courts will look through the legal form the parties choose, rather looking to the substance of the transaction. Looking at form over substance is consistent with commercial transaction law generally. Software transactions like the one in Vernor are generally considered subject to Uniform Commercial Code Article 2 on the sale of goods. To give effect to the sale, the UCC overrides contractual reservations of title if in effect a sale is what the parties enter into: "Any retention or reservation by the seller of the title (property) in goods shipped or delivered to the buyer is limited in effect to a reservation of a security interest." 239 A security interest would be of no significance in cases where the software had been fully paid for, and so there was no debt to secure. ${ }^{240}$

234. Id. ("Particularly with regard to computer software, we have recognized that copyright owners may create licensing arrangements so that users acquire only a license to use the particular copy of software and do not acquire title that permits further transfer or sale of that copy without the permission of the copyright owner.").

235. Id. at 1182 ("Because the record here is devoid of any indication that the recipients agreed to a license, there is no evidence to support a conclusion that licenses were established under the terms of the promotional statement.").

236. Id. at 1181.

237. See Vernor v. Autodesk, Inc., 621 F.3d 1102, 1104 (9th Cir. 2010).

238. Impression Prods., Inc. v. Lexmark Int'l, Inc., 137 S. Ct. 1523, 1532-35 (2017); Kirtsaeng v. John Wiley \& Sons, Inc., 568 U.S. 519, 538-39 (2013).

239. U.C.C. § 2-401(1) (Aм. Law Inst. \& Unif. Law Comm'N 1998).

240. See U.C.C. § 9-513(b)(1) (Debtor may require filing of termination statement relating to security interest if "there is no obligation secured by the collateral covered by the financing statement and no commitment to make an advance, incur an obliga- 
An argument has been made that software licenses are indeed security interests. Where a software license transfers copies of software but purports to retain ownership of the copies, one could recharacterize the transaction as transferring ownership of the software subject to a security interest. ${ }^{241}$ Even if the transaction is not a sale on credit, so there is no money debt to be secured by the software, one could argue that the software is collateral to secure the obligations of the buyer to comply with the license. ${ }^{242}$ If the buyer breaches, then the software could be repossessed. The license will contain an agreement not to transfer the software to anyone else: reselling the software would constitute a breach and trigger the right to repossess the software.

That argument would not survive after Lexmark. The Court held that contractual restraints on alienation would be overridden by the federal first sale doctrine. ${ }^{243}$ The security interest argument does nothing more than provide a means for contract law (granting of a security interest) to give effect to a property right to restrain alienation. A security interest gives a right to repossess collateral if a debt is not paid, and becomes nugatory once the debt is paid. ${ }^{244}$ The security interest view of anti-transfer clauses, by contrast, would apply where there is no debt, would last permanently, and would serve no purpose other than to prevent transfer of the software. It would allow software sellers to negate first sale with a one-line clause in the sales contract, exactly what Lexmark held ineffective. And it would not be limited to software, so sellers of books, music, paintings, and every other type of copyrighted work could benefit. First sale would become an option at the choice of copyright holders, whereas Lexmark quite clearly made first sale a restriction on patent holders, with reasoning relying on and applicable to copyright. ${ }^{245}$

When we look at how such a security interest would play out, its effect as a restraint on alienation becomes quite clear. Suppose that the retention of title was treated as the retention of a security interest and that the contract contained an anti-transfer clause. If the software

tion, or otherwise give value.”). The security interest could be significant if, as discussed in the next paragraph, it secured a contingent obligation.

241. See John F. Duffy \& Richard Hynes, Statutory Domain and the Commercial Law of Intellectual Property, 102 VA. L. REv. 1, 72 (2016) ("A court ruling in Vernor's favor on the first sale doctrine would have had to view the software copies as physical goods that can be bought and sold. That viewpoint would trigger application of the UCC, and a court applying the UCC would almost certainly have to rule that, if Autodesk's transfer of the software-on-a-disk is viewed as a sale, it would be a sale subject to Autodesk's retention of a security interest securing the obligations in the purported license.").

242. Id.

243. Impression Prods., Inc. v. Lexmark Int'l, Inc., 137 S. Ct. 1523, 1532-35 (2017).

244. See U.C.C. $\$ \S 9-610,615$ (giving creditor right to take possession of collateral upon default and right to apply the proceeds of sale of collateral to the payment of the secured debt).

245. See Lexmark, 137 S. Ct. at 1532-35. 
was resold, that would trigger a default, permitting the original seller to repossess the software. What next? The original seller could not simply keep the repossessed software. The UCC permits a repossessing creditor only to resell the collateral with prior notice. ${ }^{246}$ The repossessing creditor is not permitted to simply keep the repossessed collateral, even if that was specifically allowed in the contract; the UCC negates such a contract right of "strict foreclosure." 247 Rather, the repossessing seller would have to resell the software in a commercially reasonable manner-in other words, in the same way software vendors sell such software. ${ }^{248}$ The security interest, in effect, would simply amount to the original seller being entitled to monopolize the resale market, to the exclusion of owners of authorized copies, exactly what the first sale doctrine prohibits, as reflected in Kirtsaeng and Lexmark. $^{249}$

The question also arises, what would the creditor do with the money from reselling the software? It would be entitled to apply the money to the debt, and then return any surplus to the debtor-the person who had bought the software on resale (such as Vernor). So the result would be that the second buyer (such as Vernor) would have its property repossessed and sold to pay the obligation of the first buyer (who resold to Vernor). Lexmark allows parties to use contract law to agree between themselves about whether transfer is permissible, but does not allow those contractual agreements to be binding on third parties as a matter of patent infringement. ${ }^{250}$ But that would be the effect, if the transferred property, although no longer owned by a party to the agreement, could be collateral for any breach of the agreement. The measure of the debt would presumably be the damages from the breach of the anti-transfer clause-which raises the question of how to measure damages (or assess the reasonableness of a liquidated damages provision), where the only damage flows from reselling the property, something that a non-party to the agreement should be required to do.

To take things a little more broadly, accepting the security interest argument would open the door to restraints on alienation generally. As long as the restraint was included in a security agreement (for personal property) or mortgage (for real estate), then it could effectively bar any further alienation of the property. But courts have long struck

246. See U.C.C. $§ 9-620$ (permitting the creditor only to propose keeping the collateral in satisfaction of the debt, which debtor may reject).

247. U.C.C. $\$ 9-620$.

248. See U.C.C. $\$ 9-610$.

249. See Impression Prods., Inc. v. Lexmark Int'l, Inc., 137 S. Ct. 1523, 1532-33 (2017); Kirtsaeng v. John Wiley \& Sons, Inc., 568 U.S. 519, 538-39 (2013).

250. See Lexmark, 137 S. Ct. at 1533 ("Once sold, the Return Program cartridges passed outside of the patent monopoly, and whatever rights Lexmark retained are a matter of the contracts with its purchasers, not the patent law."). 
down restraints on alienation that were included in documents filed in the real estate records, whether deeds or mortgages. ${ }^{251}$

The second factor in the Vernor test is whether the copyright owner significantly restricts the user's ability to transfer the software. ${ }^{252}$ In contract law, this would be rightly considered in determining what rights were transferred. But in considering whether the transaction is an unreasonable restraint on alienation, the factor would cut in the other direction. The test is equivalent to asking: To what extent has the transferor imposed a restraint on alienation?

The third factor under Vernor is whether the copyright owner imposed notable use restrictions. ${ }^{253}$ This factor, unlike the other two, would remain relevant, in determining whether the transaction conveyed ownership, in substance. If a product were transferred under strict limitations on use, then it might not qualify as a transfer of ownership because the recipient did not effectively become the owner of the goods, but rather was merely a lessee or bailee of goods still belonging to the transferor. But that would take more than the sort of restrictions in Vernor and other typical software transactions. Autodesk's agreement prevented its customers from "modifying, translating, or reverse-engineering the software, removing any proprietary marks from the software or documentation, or defeating any copy protection." ${ }^{254}$ Such provisions do little more than restate rights that would accompany any sale of a copyrighted work, first sale notwithstanding. Copyright gives the copyright owner a set of exclusive rights: in short, (1) to make copies; (2) to adapt the work; (3) to distribute copies; (4) to perform the copyrighted work publicly; and (5) to display copies to the public. ${ }^{255}$ First sale insulates the owner of a copy from two of those rights. She may distribute that copy or display that copy. But first sale does not authorize her to make copies of her copy, adapt it, or perform it in public. So first sale would not permit Vernor to modify, translate, or reverse-engineer the software. ${ }^{256} \mathrm{Re}$ moving proprietary marks or defeating copy protection would likewise be barred by the anti-circumvention and copyright-information protections of the Copyright Act. ${ }^{257}$ Putting those sorts of restrictions into the contract does not detract from the transfer of the software being a sale of that particular copy.

The agreement in Vernor is a sale of the software with a restraint on alienation. Whether first sale overrides that restraint should still de-

251. See, e.g., Singer, supra note 21, at 278-79 (discussing how courts strike down disabling restraints on alienation included in deeds).

252. Vernor v. Autodesk, Inc., 621 F.3d 1102, 1111 (9th Cir. 2010).

253. Id.

254. Id.

255. See 17 U.S.C. $§ 106$ (2018).

256. Fair use might apply to some activity in those areas, especially if not for commercial purposes. See 17 U.S.C. $\$ 107(1)$ (2018).

257. Digital Millennium Copyright Act, 17 U.S.C. $§ 1202$ (2018). 
pend on whether the restraint was a reasonable restraint. Autodesk made a number of policy arguments against applying first sale, which could also be considered on the question of reasonableness:

Autodesk contends that this (1) allows for tiered pricing for different software markets, such as reduced pricing for students or educational institutions; (2) increases software companies' sales; (3) lowers prices for all consumers by spreading costs among a large number of purchasers; and (4) reduces the incidence of piracy by allowing copyright owners to bring infringement actions against unauthorized resellers. ${ }^{258}$

These are not the sort of justifications that courts have held would make restraints on alienations reasonable. Indeed, the first is simply an argument for permitting price discrimination ("tiered pricing for different software markets"), whereas first sale is intended to hinder price discrimination. ${ }^{259}$ The next two are possible, indirect effects of price discrimination (it allows the seller to make more sales by pricing differently). Lowering costs for all consumers would actually not be a goal of Autodesk, who would like to use price discrimination to charge each buyer the most they would pay, and so would only be an effect of imperfect price discrimination from lack of perfect information about the entire range of consumers. ${ }^{260}$ Reducing piracy is circular in this context. Parties reselling authorized copies under first sale are pirates only from the point of view of the frustrated copyright owner.

After the policy demarcation of Lexmark and Kirtsaeng, the trend in case law may reverse, after reexamining under the lens of restraints on alienation, rather than simply contract law. The sellers of software (and works like movies and books, which also sometimes seek to prevent resale) would not be able to unilaterally opt out of the first sale doctrine. Rather, although restraints on resale may be effective between the parties as a matter of contract law, they would not make non-parties that later purchase and resell those goods liable for infringement.

\section{Conclusion}

The Supreme Court, in Lexmark and Kirtsaeng, rooted first sale in the policy against restraints on alienation in rather absolute terms. Those cases involved rather absolute restraints on alienation, so the

258. Vernor, 621 F.3d at 1114-15.

259. Kirtsaeng v. John Wiley \& Sons, Inc., 568 U.S. 519, 552 (2013) ("To the contrary, Congress enacted a copyright law that (through the "first sale" doctrine) limits copyright holders' ability to divide domestic markets.").

260. Cf. id. at 539 ("With these last few words, Coke emphasizes the importance of leaving buyers of goods free to compete with each other when reselling or otherwise disposing of those goods. American law too has generally thought that competition, including freedom to resell, can work to the advantage of the consumer."). 
lack of subtlety was not out of place. But other restraints on alienation in the context of intellectual property are less clearly drawn. A nuanced application of the policy could change the prevailing law regarding (1) the extent of judicially created conflict preemption and (2) the extent to which federal first sale preempts state laws that have the effect of restraining alienation of property covered by patents or copyrights. Despite the visceral rejection that restraints on alienation seem to trigger in judges, some can serve purposes to benefit both parties to the original transaction and their successors, as opposed to simply tying the hands of future owners. After Lexmark and Kirtsaeng, the courts should change positions on two first-sale-related issues. First, first sale should not preempt statutes like California's Resale Royalty Act, which create only minor friction on alienation while serving a purpose completely in accord with federal copyright law. Second, courts should reverse the trend of treating software transactions as mere licenses. Rather, courts should acknowledge that where the seller delivers the software and the buyer is entitled to keep and use it freely, a sale has occurred. That sale triggers the right under first sale to resell the software, contractual restraints on alienation notwithstanding. Patent and copyright can learn much from the varied case law experience of common law property. 
